Raquel Civolani Marques Fernandes

\title{
Caracterização imunofenotípica dos carcinomas mamários pouco diferenciados
}

Tese apresentada à Faculdade de Medicina da Universidade de São Paulo para obtenção do título de Doutor em Ciências

Área de Concentração: Patologia

Orientadora: Profa. Dra. Filomena Marino Carvalho

São Paulo

2008 
Dados Internacionais de Catalogação na Publicação (CIP)

Preparada pela Biblioteca da

Faculdade de Medicina da Universidade de São Paulo

Creprodução autorizada pelo autor

Fernandes, Raquel Civolani Marques

Caracterização imunofenotípica dos carcinomas mamários pouco diferenciados / Raquel Civolani Marques Fernandes. -- São Paulo, 2008.

Tese(doutorado)--Faculdade de Medicina da Universidade de São Paulo. Departamento de Patologia.

Área de concentração: Patologia.

Orientadora: Filomena Marino Carvalho.

Descritores: 1.Carcinoma 2.Neoplasias mamárias 3.Imunoistoquímica 4.Fenótipo 5.Expressão gênica

USP/FM/SBD-138/08 


\section{Dedicatória}

Dedico esta tese à Deus por ter me dado saúde e inspiração, Aos meus pais, Cecília e Rubens, pelo esforço que sempre fizeram pela minha formação Ao meu marido, Guilherme, e aos meus filhos Henrique e Beatriz, razões de minha vida. 


\section{Agradecimentos}

É com muito orgulho e alegria que finalizo mais esta conquista e gostaria de agradecer as pessoas que me ajudaram a chegar até aqui:

Agradeço aos meus pais, Cecília e Rubens, pelo lar tranqüilo, repleto de amor e pelo apoio e confiança que sempre me deram.

Ao meu amado esposo Guilherme, que sempre esteve ao meu lado, pela paciência, companheirismo, respeito e amor por mim.

Aos meus filhos, Henrique e Beatriz, pelo amor e paciência que tiveram durante as noites as quais não pude dar-lhes toda a atenção que mereciam.

Ao meu irmão, Daniel, pela amizade e confiança que sempre demonstrou por mim.

À querida Profa. Dra. Filomena Marino Carvalho, minha orientadora, pela inesgotável paciência, sabedoria, competência e dedicação ao trabalho, pessoa responsável pelo grande interesse que tenho na patologia ginecológica e mamária.

À Profa. Dra. Sheila Aparecida Coelho Siqueira, querida amiga, pelos ensinamentos desde a residência médica e por ter supervisionado as reações imunoistoquímicas deste trabalho.

Ao Prof. Dr. José Luiz Barbosa Bevilacqua, colega mastologista do Hospital Sírio Libanês, por ter realizado a análise estatística deste trabalho e pelos conselhos durante os dois últimos anos.

Ao Prof. Dr. Roberto Hegg, Professor do Departamento de Ginecologia e Obstetrícia da Faculdade de Medicina da Universidade de São Paulo, pelo suporte financeiro para a realização das reações imunoistoquímicas.

Ao Prof. Dr.Venâncio Avancini Ferreira Alves, Professor Titular da Faculdade de Medicina da Universidade de São Paulo, por ter disponibilizado os recursos do Laboratório de Investigação Médica 14 do Hospital das Clínicas da Faculdade de Medicina da Universidade de São Paulo para a construção do bloco de tissue microarray.

Ao Dr. Iberê Cauduro Soares, colega patologista, pela disponibilidade de ajuda na preparação e construção do bloco de tissue microarray.

À querida amiga patologista Dra. Rute Facchini Lellis, pelo constante incentivo e coberturas nas horas de minha ausência. 
Às amigas da residência médica, Dras. Cristiane Rúbia Ferreira e Fabiana Roberto Lima pelo constante apoio e inúmeros conselhos.

Ao Dr. Luis Pires (Departamento de Ginecologia e Obstetrícia da Faculdade de Medicina da Universidade de São Paulo), pela ajuda no levantamento dos casos.

Às Sras Neila Aparecida de Souza Silva, Marta Mitiko Otta e Rita de Cássia A. M. Góis Pinto (Divisão de Patologia Cirúrgica da Faculdade de Medicina da Universidade de São Paulo), pela realização técnica das reações imunoistoquímicas.

À Sra. Alda Wakamatsu ( Laboratório de Investigação Médica 14 do Hospital das Clínicas da Faculdade de Medicina da Universidade de São Paulo) pela supervisão na preparação e construção do bloco de tissue microarray.

Ao Sr. Josué Moreira de Souza, pela editoração desta tese.

Aos Srs. Douglas Moreira e Hermogênio Rafael de Oliveira (Divisão de Patologia Cirúrgica da Faculdade de Medicina da Universidade de São Paulo), pela cuidadosa separação de todas as lâminas e blocos originais de todas as pacientes.

Agradeço aos médicos patologistas e funcionários da Divisão de Patologia Cirúrgica da Faculdade de Medicina da Universidade de São Paulo pela compreensão e amizade constante.

Às pacientes, meus profundos agradecimentos. 
Esta tese está de acordo com: as seguintes normas, em vigor no momento desta publicação:

Referências: adaptado de International Committee of Medical Journals Editors (Vancouver)

Universidade de São Paulo. Faculdade de Medicina. Serviço de Biblioteca e Documentação. Guia de apresentação de dissertações, teses e monografias. Elaborado por Annelise Carneiro da Cunha, Maria Julia A. L. Freddi, Maria F. Crestana, Marinalva de Souza Aragão, Suely Campos Cardoso, Valéria Vilhena. São Paulo: Serviço de Biblioteca e Documentação; 2005.

Abreviatura dos títulos dos periódicos de acordo com List of Journals Indexed in Index Medicus. 


\section{Sumário}

Lista de Abreviaturas

Lista de Figuras

Lista de Tabelas

Resumo

Summary

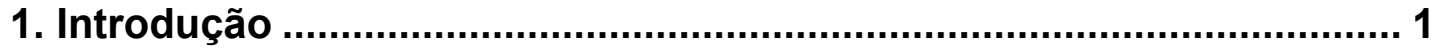

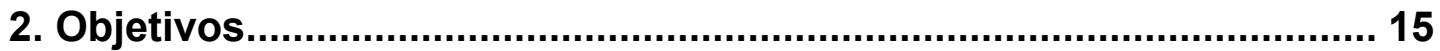

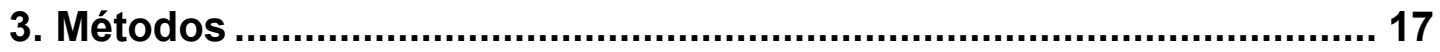

3.1 Certificação Institucional ....................................................... 18

3.2 Seleção dos casos ....................................................... 18

3.3 Exame anatomopatológico .............................................. 19

3.4 Construção do bloco pela técnica de arranjo em matriz de amostras

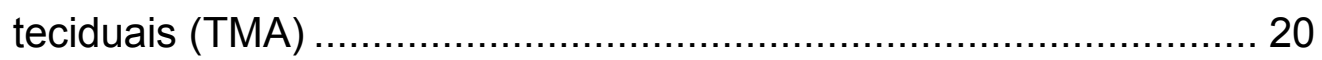

3.5 Exame imunoistoquímico .................................................... 22

3.6 Interpretação das reações imunoistoquímicas ............................... 25

3.7 Análise estatística ............................................................... 28

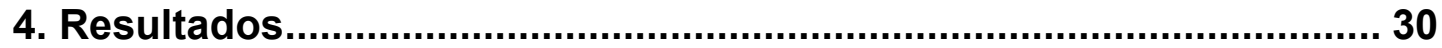

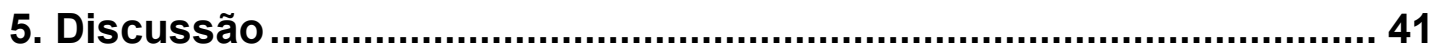

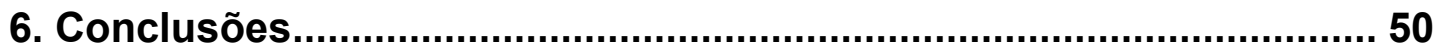

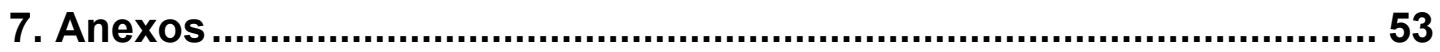

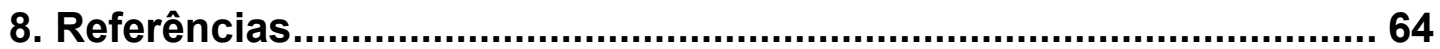

Apêndice 


\section{Lista de abreviaturas}

$\begin{array}{ll}\text { RE } & - \text { Receptor de Estrógeno } \\ \text { RP } & - \text { Receptor de Progesterona } \\ \text { HER2 } & - \text { Receptor do fator de crescimento epidérmico humano } 2 \\ \text { EVL } & - \text { embolização vascular linfática } \\ \text { CK } & - \text { citoqueratina } \\ \text { col. } & - \text { colaboradores } \\ \text { EGFR (HER1) } & - \text { receptor do fator de crescimento epidérmico } \\ \text { VEGF } & - \text { fator de crescimento endotelial vascular } \\ \text { FGFs } & - \text { fator de crescimento de fibroblastos } \\ \text { PDGF } & - \text { fator de crescimento plaquetário } \\ \text { RH } & - \text { receptores hormonais } \\ \text { CDIS } & - \text { Carcinoma Ductal "in situ" } \\ \text { VS } & - \text { versus }\end{array}$

CK5, CK14 e CK17 - citoqueratinas basais

CK8/18 - citoqueratinas luminais

$\mathrm{pN}(+) \quad$ - presença de comprometimento axilar

TN - Triplo Negativo (RE-/RP-/HER2-)

ASCO - Sociedade Americana de Oncologia Clínica

CAP - Colégio Americano de Patologistas

TMA - arranjo em matriz de amostras teciduais (tissue microarray) 


\section{Lista de Figuras}

Figura 1 - Preparação do bloco de TMA ............................................21

Figura 2 - Sistema de transferência de cortes histológicos por selos ...........22

Figura 3 - Lâmina do TMA corada por hematoxilina-eozina .......................22

Figura 4A - Marcação nuclear para receptor de estrogênio ........................26

Figura 4B - Marcação nuclear para receptor de progesterona ....................26

Figura 4C - Marcação nuclear para Ki67 ..............................................26

Figura 4D - Marcação nuclear para p63 .............................................26

Figura 5A - Marcação de membrana 3+/3+ para HER2 .............................26

Figura 5B - Marcação de membrana para EGFR ..................................26

Figura 6A - Marcação citoplasmática para CK5 ......................................27

Figura 6B - Marcação citoplasmática para CK14 ..................................27

Figura 6C - Marcação citoplasmática para CK17 .................................27

Figura 6D - Marcação citoplasmática para CK8/18 ...............................27

Figura 6E - Marcação citoplasmática para c-Kit...................................27

Figura 6F - Marcação citoplasmática para VEGF-A............................27

Figura 7A - Carcinoma pouco diferenciado de mama com padrão arquitetural sólido

Figura 7B - Carcinoma pouco diferenciado de mama com extensas áreas de necrose de padrão geográfico

Figura 7C - Carcinoma pouco diferenciado de mama com bordas expansivas e resposta linfocítica estromal periférica 


\section{Lista de Tabelas}

Tabela 1 - Detalhes da metodologia das reações imunoistoquímicas ........23

Tabela 2 - Características clínico-patológicas dos carcinomas de mama de acordo com os perfis imunoistoquímicos básicos

Tabela 4 - Grupos triplo-negativo e não triplo-negativo e suas relações com múltiplas variáveis clínica-patológicas.

Tabela 5 - Citoqueratinas basais e suas relações com as múltiplas variáveis clínica-patológicas

Tabela 6 - Regressão Logística Binária - Fatores preditivos independentes dos tumores triplo-negativos.

Tabela 7 - Regressão Logística Binária - Fatores preditivos independentes da expressão de citoqueratinas basais

Tabela 8 - Características clínico-patológicas comparativas entre carcinomas com perfil imunoistoquímico basal-símile (triplonegativo e CK basal) e os demais subgrupos 39

Tabela 9 - Comparação múltipla entre os subgrupos .40 


\section{Resumo}

Fernandes RCM. Caracterização imunofenotípica dos carcinomas mamários pouco diferenciados [tese]. São Paulo: Faculdade de Medicina, Universidade de São Paulo; 2008. 71p.

INTRODUÇÃO: O grau histológico é um dos principais fatores prognósticos em câncer de mama. Entretanto, os carcinomas pouco diferenciados ainda constituem um grupo bastante heterogêneo de tumores, pois podem corresponder a qualquer um dos subgrupos segundo a classificação genética: basal-símile, HER2, luminal ou mama-normal. OBJETIVOS: Neste estudo nós analisamos a freqüência dos perfis imunoistoquímicos básicos quanto à expressão de receptores de estrógeno e progesterona e HER2 em carcinomas de mama com menos de $10 \%$ de formação tubular e suas relações com fatores prognósticos clássicos e com a expressão de p63, cKit, EGFR, VEGF-A e citoqueratinas basais e luminais. MATERIAL E MÉTODOS: Este estudo retrospectivo incluiu 134 carcinomas de mama selecionados dos arquivos da Divisão de Patologia Cirúrgica da Faculdade de Medicina da Universidade de São Paulo, de 2000 a 2003. Os tumores foram revistos e classificados quanto à expressão imunoistoquímica de receptor de estrogênio, receptor de progesterona e HER2 nos perfis luminal (receptores hormonais positivos), HER2 (HER2 positivo e receptores hormonais negativos) e triplo-negativo. O subgrupo luminal foi subdividido quanto à expressão ou não de HER2. O exame imunoistoquímico para p63, citoqueratinas basais 5, 14 e 17,VEGF-A, EGFR, c-Kit e citoqueratinas luminais $8 / 18$ foram feitos em bloco construídos pela técnica de arranjo em matriz de amostras teciduais. As variáveis prognósticas clássicas: idade da paciente, tamanho do tumor, estado linfonodal, grau nuclear, necrose tumoral, contagem mitótica e embolização vascular linfática, foram comparadas nos diferentes subgrupos. RESULTADOS: Os carcinomas mamários invasivos pouco diferenciados confirmaram sua heterogeneidade. O subtipo luminal foi o mais freqüente (73 casos), seguido pelo subtipo triplonegativo (39 casos) e do subtipo HER2 (22 casos). O subgrupo triplonegativo apresentou a maior proporção de tumores maiores que $2,0 \mathrm{~cm}$, maior freqüência de necrose e a maior taxa de expressão de citoqueratinas basais. Este subgrupo juntamente com o subgrupo HER2 expressaram maiores índices de proliferação celular. O subgrupo HER2 mostrou maior número de casos associados à presença de componente "in situ" e maior freqüência de detecções de embolização vascular linfática. O subgrupo luminal apresentou o maior número de casos com expressão de citoqueratinas luminais $8 / 18$ e o menor número de tumores maiores que 2,0 $\mathrm{cm}$. Quanto à expressão de citoqueratinas basais, 81 casos não as expressaram e 53 expressaram pelo menos uma delas, a maioria destes casos pertencentes ao subgrupo triplo-negativo. O fenótipo triplo-negativo esteve intimamente relacionado à expressão de citoqueratinas basais. Dentre todas as variáveis estudadas, o único fator preditivo independente associado ao perfil triplo-negativo foi a expressão de citoqueratinas basais 
$(p<0.0001)$ e o único fator preditivo independente associado à expressão de citoqueratinas basais foi a presença do fenótipo triplo-negativo $(p<0,0001)$. O subgrupo basal-símile (tumores triplo-negativo com expressão de pelo menos uma citoqueratina basal) mostrou a maior freqüência de tumores > $2,0 \mathrm{~cm}$ e conjuntamente com o subgrupo triplo-negativo não basal-símile, a maior freqüência de tumores com presença de necrose e com alta contagem mitótica. A comparação entre os carcinomas HER2(+) quanto à expressão de receptores hormonais mostrou maiores indicadores de atividade proliferativa no grupo de receptores hormonais (-). Por outro lado, tumores positivos para os receptores de estrógeno e/ou progesterona com o sem expressão HER2 não mostraram qualquer diferença. CONCLUSÕES: O subgrupo de tumores com receptores hormonais positivos foi $O$ mais freqüente e com características morfológicas e imunoistoquímicas mais favoráveis que os outros subgrupos, independente da expressão de HER2, sugerindo que carcinomas de mama pouco diferenciados com expressão de pelo menos um dos receptores hormonais correspondem ao subtipo luminal $B$ genético. Os carcinomas pouco diferenciados com imunofenótipo triplonegativo e HER2(+) são similares quanto às características morfológicas associadas à doença com potencial agressivo. No entanto, a expressão das citoqueratinas basais diferenciam os dois subgrupos, e pode sugerir 0 fenótipo basal-símile e o padrão de doença associado a este fenótipo. Nosso estudo mostrou que entre os carcinomas de mama pouco diferenciados de mama, o painel imunoistoquímico clássico (receptores hormonais e HER2) associado à expressão de pelo menos uma das citoqueratinas basais permitem a identificação dos distintos subtipos, equivalentes aos vistos na classificação genética.

Descritores: 1.Carcinoma; 2.Neoplasias mamárias; 3.Imunoistoquímica; 4.Fenótipo; 5.Expressão gênica. 


\section{Summary}

Fernandes RCM. Immunophenotype characterization of poorly differentiated breast carcinomas [thesis]. São Paulo: Faculdade de Medicina, Universidade de São Paulo; 2008. 71p.

INTRODUCTION: Histological grade is one of the main prognostic factors for breast cancer. However, poorly differentiated carcinomas still make up a quite heterogeneous group of tumors since they can belong to any of the subgroups according to genetic classification: basal-like, HER2, luminal or normal breast. OBJECTIVES: In this study we have analyzed the frequency of the basic immunohistochemical profiles as for the expression of estrogen and progesterone receptors and HER2 in breast cancer with less than $10 \%$ of tubular formation, and their relation with classic prognostic factors, expression of p63, c-Kit, EGFR, VEGF-A, basal and luminal cytokeratins. MATERIAL AND METHODS: This retrospective study included 134 breast carcinomas dated between 2000 and 2003, selected from the files from the Division of Surgical Pathology, University of São Paulo Medical School. All slides were revised and classified according to immunohistochemical expression of estrogen receptor, progesterone receptors and HER2 in luminal (positive hormonal receptors), HER2 (positive HER2 and negative hormonal receptors) and triple-negative. The luminal subgroup was further divided according to expression or absence of HER2. Immunohistochemical marking for p63, cytokeratins 5, 14 and 17 and 8/18, VEGF-A, EGFR, c-Kit was done through tissue microarray. The classical prognostic variables: age, tumor size, lymph node state, nuclear grade, tumor necrosis, mitotic count and lymphatic vascular embolization were compared among the different subgroups. RESULTS: The poorly differentiated invasive breast carcinomas confirmed their heterogeneity. The luminal subtype was the most frequent (73 cases), followed by the triple-negative (39 cases) and HER2 (22 cases). The triple-negative subgroup presented the highest proportion of tumors bigger than $2.0 \mathrm{~cm}$, necrosis and higher basal cytokeratin rate expression. This subgroup as well as HER2 subgroup expressed higher cellular proliferation scores. The HER2 subgroup presented the highest number of cases associated with "in situ" component and higher frequency of lymphatic vascular embolization detection. The luminal subgroup presented the highest expression of luminal cytokeratins $8 / 18$ and the least number of tumors larger than $2.0 \mathrm{~cm}$. As for basal cytokeratin expression, 81 cases did not present any cytokeratin at all and 53 at least one, most of them belonging to the triple-negative subgroup. The triple-negative phenotype was intimately related to the expression of basal cytokeratins. Among all the variables studied, the only independent predictive factor associated with triple-negative profile was the presence of basal cytokeratin $(p<0.0001)$, and the only independent predictive factor associated with basal cytokeratin expression was the presence of triple-negative phenotype $(p<0.0001)$. The basal like subgroup (triple-negative tumors with the expression of at least one basal cytokeratin) showed the highest frequency of tumors larger than $2.0 \mathrm{~cm}$, and 
together with the non-basal like, the highest frequency of tumors with necrosis and high mitotic count. The comparison between HER2 (+) carcinomas as far as hormonal receptors, showed higher proliferative activity in the group of negative hormonal receptors. On the other hand, tumors positive for estrogen and/or progesterone receptors with or without HER2 expression did not present any difference. CONCLUSIONS: The tumor subgroup with positive hormonal receptors was the most frequent and with more favorable morphological and imunohistochemical characteristics than the other subgroups, independent of HER2 expression, suggesting poorly differentiated breast carcinomas with the expression of at least one of the hormonal receptors correspond to luminal B genetic subgroup. The poorly differentiated carcinomas with triple-negative and HER2(+) immunophenotype are similar in relation to morphological characteristics associated to the disease with aggressive potential. However, the expression of basal cytokeratins differs the two subgroups and can suggest the basal-like phenotype and the disease evolution associated with it. Our study showed that among poorly differentiated breast carcinomas, the classic immunohistochemical panel (hormonal receptors and HER2) associated with the expression of at least one of the basal cytokeratins, allow the identification of the specific subtypes, similar to the ones seen in genetic classification.

Descriptors: 1.Carcinoma; 2.Breast neoplasms; 3.Immunohistochemistry; 4.Phenotype; 5.Gene expression. 
1. Introdução 
No Brasil, o câncer de mama é a neoplasia maligna mais freqüente e a maior causa de óbitos por câncer na população feminina, principalmente na faixa etária entre 40 e 69 anos ${ }^{(1)}$. Representa, ainda, um dos grupos de neoplasias mais estudadas quanto à pesquisa de fatores prognósticos e preditivos. Entretanto, em que pese o reconhecimento de variáveis já bem estudadas e estabelecidas, mesmo em reuniões de consenso de impacto mundial, a individualização dos casos continua a gerar dúvidas. Tal fato se deve a heterogeneidade da doença, que, segundo tendência atual decorrente de melhor compreensão dos mecanismos de carcinogênese, provavelmente não corresponde a uma única entidade, mas a um conjunto de tumores que refletem proliferação clonal de células progenitoras neoplásicas com capacidade de autorenovação e de gerar células neoplásicas com padrões de diferenciação que dependem da célula iniciada e meio ambiente ${ }^{(2-4)}$. Assim, a heterogeneidade tumoral seria reflexo de capacidade maior ou menor de diferenciação por parte das células progenitoras neoplásicas. .

Após décadas de muita pesquisa nos fatores preditivos e prognósticos, os fatores clássicos, como estadiamento, tipo e grau histológico, expressão de receptores hormonais e, mais recentemente, super-expressão do gene receptor do fator de crescimento epidérmico humano 2 (HER2), continuam a 
nortear as decisões terapêuticas. O Colégio Americano de Patologistas definiu como fatores prognósticos e/ou preditivos categoria 1, ou seja, suficientemente estudados e comprovados quanto a utilidade na prática clínica o estadiamento, tipo e grau histológico, contagem mitótica e expressão imunoistoquímica dos receptores hormonais e do HER2 ${ }^{(5 ; 6)}$.

A rigor, nenhum dos fatores ainda supera o estado axilar. Mirza e col. ${ }^{(7)}$ em metanálise de trabalhos com avaliação de fatores prognósticos para pacientes com axila negativa, selecionaram 52 trabalhos entre 4462 títulos e 753 resumos através dos seguintes critérios: mais de 200 casos, seguimento médio superior a 5 anos, metodologia estatística adequada para comparações, sobrevida geral e livre de doença especificada e riscos relativos calculados. Os autores observaram que o tamanho do tumor, grau histológico, expressão de catepsina $D$, fração de fase $S$, embolização vascular e contagem mitótica foram as variáveis significativas na previsão da sobrevida livre de doença e sobrevida geral.

$\mathrm{Na}$ reunião de St. Gallen, em 2007, as categorias de risco mantiveram-se semelhantes às definidas em 2005, ou seja: baixo risco, composto pelos casos axila negativa com todas as características favoráveis (tumor invasivo $\leq 2,0 \mathrm{~cm}$, grau histológico e/ou nuclear $=1$, receptor de estrogênio (RE) e/ou receptor de progesterona (RP) positivos, HER2 negativo, ausência de invasão vascular extensa e idade de 35 anos ou mais), risco intermediário, correspondente aos casos de pacientes com axila negativa e pelo menos uma característica desfavorável (tumor maior do que $2,0 \mathrm{~cm}$, grau histológico e/ou nuclear $=2$ ou $3, \mathrm{RE} / \mathrm{RP}$ negativos, HER2 
positivo, presença de embolização vascular extensa e idade inferior a 35 anos) ou a casos com 1 a 3 linfonodos positivos e RE/RP positivos e HER2 negativo e alto risco, correspondentes a casos com 4 ou mais linfonodos positivos ou 1 a 3 linfonodos positivos e RE/RP negativos ou HER2 positivo) ${ }^{\left({ }^{8}\right)}$. As novidades em relação a 2005 foram: a) a invasão vascular peritumoral tem que ser extensa para justificar um aumento de risco (êmbolos neoplásicos notados em $\geq 2$ blocos de tumor), b) alguns tipos histológicos devem ser considerados de baixo risco apesar da ausência de receptores hormonais, como o carcinoma medular e o carcinoma apócrino e c) a expressão de receptores hormonais e a superexpressão ou amplificação do HER2 constituem fatores de risco, assim como alvos terapêuticos. Em St. Gallen se enfatizou a abordagem inicial dos carcinomas segundo grau de responsividade hormonal, seguido dos indicadores de terapia sistêmica.

A desproporcional escassez de fatores comprovados e de aplicação prática é fruto da heterogeneidade dos tumores e conseqüente dificuldade em se controlar todas as variáveis que podem interferir no resultado. Também interfere a metodologia utilizada, quase sempre operadordependente ou laboratório-dependente.

A despeito do grande número de fatores prognósticos já testados, somente dois: o receptor de estrogênio e a super-expressão de HER2, se consolidaram até o presente como alvos terapêuticos.

A heterogeneidade dos carcinomas de mama é decorrente do envolvimento de diferentes genes, relacionados à atividade proliferativa, diferenciação e supressão de tumores, vários deles estudados isoladamente 
ou em pequenos grupos, quanto à implicação na carcinogênese e/ou como fatores prognósticos. Entretanto, a enorme heterogeneidade e o número de fatores envolvidos dificultam a interpretação. Com o desenvolvimento das tecnologias de análise do genoma com possibilidades de análise concomitante de milhares de genes, foi possível se identificar nos tumores de mama, perfis gênicos intrínsecos, denominados basal, HER2, luminais $A$, B e C, e tipo mama normal ${ }^{(9-13)}$. Estes perfis de apresentação mostraram consistência mesmo em diferentes grupos de estudo e utilizando técnicas diferentes de arrays ${ }^{(10 ; 11 ; 13 ; 14)}$.

O carcinoma do subtipo tipo basal foi caracterizado pela alta expressão de vários genes que caracterizam as células basais do epitélio, que na unidade ducto terminal lobular têm a capacidade de originar células epiteliais e mioepiteliais, incluindo as citoqueratinas basais 5/6 e 17, marcadores de atividade proliferativa e marcadores indicativos de diferenciação muscular lisa, presentes em células mioepiteliais e suas precursoras ${ }^{(15)}$. Outros marcadores foram agregados a estes no sentido de melhor acurácia na determinação do fenótipo e da evolução esperada para estes tumores, entre eles, expressão do receptor do fator de crescimento epidérmico 1 (EGFR) ou HER1, c-Kit e vimentina. Este subgrupo de carcinomas corresponde a $15 \%$ dos cânceres de mama e reflete a célula mais indiferenciada, sem expressão de receptores hormonais ou HER2 (triplo-negativo). Os tumores de fenótipo basal correspondem, em geral, a carcinomas de alto grau e carcinomas metaplásicos ${ }^{(9 ; 16-18)}$. 
Livasy e col e Nielsen e col. ressaltaram, ainda, algumas características morfológicas freqüentemente presentes nestes subtipos de tumores ${ }^{(17 ; 18)}$. Entre elas foram citadas o alto grau histológico e nuclear, alta contagem mitótica, presença de células poligonais com citoplasma abundante, eosinofílico ou claro, necrose tumoral geográfica, cicatriz central, bordas tumorais expansivas e resposta linfocítica estromal.

Os tipos luminais mostram perfil de células epiteliais diferenciadas, com expressão de receptores hormonais e melhor prognóstico, particularmente o subtipo A. Estes tumores expressam marcadores das células epiteliais do revestimento ductal, como citoqueratinas luminais (8 e 18) e refletem etapa mais avançada na diferenciação, constituindo um grupo mais heterogêneo quanto ao grau de diferenciação.

A tecnologia de microarrays de DNA permitiu que subgrupos de tumores fossem analisados com o intuito de se determinar genes relacionados a características morfológicas de reconhecido impacto prognóstico. Assim, carcinomas RE-positivos foram subdividos em alto e baixo grau genômico, determinado pela expressão de genes relacionados à diferenciação e proliferação celulares ${ }^{(19)}$. Neste estudo, o grau genômico determina dois subtipos distintos de tumores quanto a evolução, independente do uso de tamoxifeno e consistentes com os perfis luminal A e B.

Ainda no grupo de carcinomas RE-positivos, o mais freqüente e mais heterogêneo, foram desenvolvidos os testes genéticos mais importantes na prática hoje, como o índice de recorrência à distância determinado por 21 genes ${ }^{(20)}$ e o teste de 70 genes de Amsterdam ${ }^{(21)}$. 
Em relação à resposta aos agentes quimioterápicos, Rouzier e col. avaliaram os subtipos genéticos basal, HER2 e luminal quanto à resposta à quimioterapia neoadjuvante com paclitaxel, fluoracil, doxorubicina e ciclofosfamida. Os autores observaram resposta patológica completa em $45 \%$ dos casos de subtipo basal, $45 \%$ no subtipo HER2 e somente $6 \%$ no subtipo luminal.

Com a possibilidade de comparação entre perfil imunoistoquímico e perfil definido pela análise de vários genes, Nielsen e col. ${ }^{(17)}$ demonstraram que um painel composto por quatro marcadores, o receptor de estrogênio negativo, HER1 positivo, HER2 negativo e citoqueratinas (CK) basais positivas, poderiam identificar com acurácia o subgrupo basal determinado geneticamente. Para fins de orientação terapêutica, as expressões de receptores hormonais e HER2 dividem, na prática, os carcinomas mamários nos subgrupos luminal, HER2 e triplo- negativo, este último incluindo os basal-símiles ${ }^{(23)}$. Sotiriou e col. ${ }^{(12)}$ encontraram no receptor de estrogênio o principal discriminador entre subgrupos basal e luminal seguido, de longe, pelo grau histológico. Curiosamente, alguns trabalhos isolados já apontavam a expressão imunoistoquímica de citoqueratinas basais nos tumores de mama como fator relacionado à maior agressividade ${ }^{(24-27)}$.

O grupo de neoplasias HER2 positivas foi inicialmente aquele associado a piores indicadores de sobrevida até que começaram a se desenvolver as terapias alvo, entre eles o anticorpo humanizado monoclonal trastuzumabe. Este último, em testes clínicos prospectivos randomizados reduziram o risco de recorrência e mortalidade pela metade e um terço, 
respectivamente, em pacientes com câncer de mama em estádio precoce ${ }^{(28-31)}$. Muitos estudos ainda ressaltaram a importância do trastuzumabe na melhora da taxas de resposta, tempo de progressão e mesmo sobrevida quando usado como único alvo terapêutico ou somado à quimioterapia em pacientes com carcinoma de mama metastático ${ }^{(32)}$. No entanto o tratamento com esta droga é dispendioso e apresenta riscos, sobretudo o potencial cardiotóxico, portanto necessitando de adequada determinação laboratorial ${ }^{(33)}$.

O HER2 pertence à família de quatro receptores transmembrana (HER1 ou EGFR, HER2, HER3 e HER4), que usam a atividade da tirosinoquinase como gatilho na sinalização celular. Outros membros da família dos receptores de fator de crescimento tirosino-quinase são o c-Kit e o receptor do fator de crescimento endotelial vascular (VEGFR), fatores que inicialmente foram estudados na avaliação do prognóstico do câncer de mama, e hoje é sabido que usam as mesmas vias de ativação que o HER2. A positividade para HER2 parece estar associada com relativa, porém não absoluta resistência à terapia endócrina em geral ${ }^{(34)}$. Estudos têm sugerido que este efeito é específico com o RE, já que a via não genômica de atuação do RE passa pelas mesmas vias do HER, o que justificaria a falha de resposta ao bloqueio hormonal e a resistência ao tamoxifeno ${ }^{(35)}$. Resultados retrospectivos sugeriram que a positividade para HER2 estaria associada à resposta com antracíclicos; no entanto este efeito poderia ser secundário a co-amplificação do gene da proteína topoisomerase II alpha (TOP2A), alvo direto destes agentes, e, portanto outro marcador com potencial terapêutico ${ }^{(36 ; 37)}$. 
O grande desafio para caracterização do grupo HER2 foi a adequada padronização laboratorial. A Sociedade Americana de Oncologia Clínica (ASCO) e o Colégio Americano de Patologistas (CAP) normatizaram critérios de positividade e controle laboratorial para teste adequado ${ }^{(6)}$.

A identificação do subtipo basal-símile é de importância crucial quanto à seleção de grupos especiais. Trata-se de subtipo freqüentemente relacionado à mutação do BRCA1. Lakhani e col. ${ }^{(38)}$ avaliaram 182 casos de pacientes com mutação do BRCA1, 63 com mutação do BRCA2 e 102 controles quanto à expressão de várias citoqueratinas basais e HER1. Observaram maior expressão das citoqueratinas basais e do HER1 nas pacientes com mutação do BRCA1, sugerindo que tumores pouco diferenciados, negativos para receptores de estrogênio e com expressão de citoqueratinas basais poderiam ser utilizados para seleção de pacientes para o teste genético. A freqüente associação com a expressão do HER1 abre uma perspectiva para novo alvo terapêutico através de inibidores do receptor do $\operatorname{EGF}^{(39 ; 40)}$.

Além do HER1, outro proto-oncogene que provavelmente influencia na carcinogênese mamária e codifica outro fator de crescimento transmembrana tirosina kinase é o c-Kit (CD117) ${ }^{(41)}$. Nielsen e col em $2004^{(17)}$ mostraram a relação entre tumores de mama de subtipo basal e a expressão de c-Kit, sendo a maior parte destes tumores c-Kit positivos não influenciando, no entanto, no prognóstico.

Ainda comentando sobre a carcinogênese, a angiogênese é um evento precoce e pode facilitar a progressão tumoral e metástases. Muitos 
fatores de crescimento com atividade angiogênica têm sidos descritos, entre eles estão o fator de crescimento de fibroblastos (FGFs), fator de crescimento plaquetário (PDGF) e o fator de crescimento endotelial vascular (VEGF) ${ }^{(42)}$.

O VEGF é uma proteína básica dimérica glicosilada que pesa 34 a $42 \mathrm{kDa}$ e que é codificada por gene localizado no braço curto do cromossomo $6(6 \mathrm{p} 21.1)^{(43)}$. O VEGF tem múltiplas isoformas, as quais possuem propriedades distintas e que afetam a disponibilidade e função sinalizadora da angiogênese diferentemente. Esta proteína pertence a uma família de fatores de crescimento com atividade mitogênica específica para a célula endotelial com conseqüente estimulação da angiogênese "in vivo".

Ribeiro-Silva e col. ${ }^{(44)}$, citaram que a expressão para o VEGF foi elevada nos carcinomas mamários positivos para a CK5 $(p=0.0207)$. Como o VEGF é o principal regulador da angiogênese ${ }^{(45)}$ e sendo a angiogênese uma etapa fundamental para a infiltração dos carcinomas, este achado sugere que o VEGF possa ser um dos fatores que justifique o comportamento clínico mais agressivo dos carcinomas que expressam a CK5.

Estes tumores têm demonstrado, além da expressão imunoistoquímica de citoqueratinas basais CK5/6 e CK14 e CK17, e do HER1, outros marcadores, tais como p-caderina e p63 ${ }^{(46-50)}$.

O fato do subgrupo basal-símile poder ser identificado através de vários marcadores, o torna, provavelmente, menos homogêneo do que a princípio indicava-se, o que não deve ser de se estranhar se considerarmos que a célula progenitora neoplásica é bipotente e origina células progenitoras intermediárias, outros possíveis alvos da transformação neoplásica ${ }^{(51)}$. 
Novos conhecimentos acerca da carcinogênese mamária têm colaborado na melhor compreensão da apresentação da doença. Os estudiosos da patologia mamária, em geral, se preocuparam com a origem do carcinoma a partir de lesões intraepiteliais e, mais recentemente, a partir de alterações moleculares. O processo da carcinogênese nesse contexto tem sido classicamente descrito como aquisição progressiva e linear de fenótipos mais agressivos com possibilidade das células neoplásicas perderem progressivamente a diferenciação e invadirem localmente e à distância. A progressão neoplásica que culmina em determinado fenótipo, com maior ou menor agressividade biológica, é, em geral, interpretado como um processo de perda de diferenciação celular progressiva. Entretanto, podemos fazer o raciocínio inverso. Sell e Pierce, em 1994, propuseram a origem das neoplasias a partir da célula progenitora. Segundo estes autores, as células progenitoras do tecido normal derivam das células progenitoras fetais, que têm a capacidade de originar o tecido adulto. As células progenitoras na neoplasia, derivadas das correspondentes normais, teriam capacidade de originar uma caricatura do tecido normal. $\mathrm{O}$ fenótipo da neoplasia, segundo esta teoria, não seria um processo de indiferenciação, mas sim de menor ou maior diferenciação. O grau de diferenciação dos carcinomas, ou seja, o seu fenótipo no momento do diagnóstico, seria função da proporção de células progenitoras tumorais indiferenciadas, do estágio de parada de maturação da maioria destas células e da habilidade de células progenitoras escaparem da parada de maturação e se diferenciarem ${ }^{(52)}$. 
O carcinoma da mama, neste modelo, seria o resultado de eventos na célula progenitora normal originando a célula progenitora iniciada ou célula progenitora neoplásica. Esta célula poderia se renovar originando células geneticamente similares ou se diferenciarem gerando células neoplásicas com diferentes perfis genéticos ao longo de toda linhagem que potencialmente a célula progenitora pode alcançar, desde células basais até epiteliais, com diferentes graus de diferenciação, com possibilidade, inclusive, de diferenciação para células mioepiteliais, justificando carcinomas com células neoplásicas que exibem fenótipo mioepitelial, como os carcinomas metaplásicos ${ }^{(53)}$.

Em 1998, Kordon e Smith ${ }^{(54)}$, demonstraram através de técnica de transplantes múltiplos de células mamárias de ratos "in vitro" que células multipotentes ao longo da árvore mamária têm a capacidade de autorenovação e podem gerar todos os tipos celulares da glândula mamária. No desenvolvimento da glândula mamária humana as células progenitoras, progressivamente, restringem sua capacidade de proliferação e opções de diferenciação. Podemos reconhecer três tipos de células progenitoras: luminal restrita, bipotente com capacidade de gerar células epiteliais e mioepiteliais, e mioepitelial restrita. A expressão de MUC1 em tecido mamário normal distingue os diferentes tipos de células progenitoras na medida em que se expressa nas células recrutadas como luminais ${ }^{(55)}$.

Behbod e Rosen ${ }^{(56)}$, em excelente revisão sobre o assunto, apontam vários marcadores que identificam células da árvore mamária nos diferentes estágios de diferenciação e que foram estudados pelos mais diferentes 
métodos definindo células progenitoras normais e neoplásicas, células basais, células mioepiteliais e células luminais.

O componente "in situ" nos carcinomas basal-símile foi estudado em dois trabalhos. Bryan e col em $2006^{(57)}$ afirmaram que o carcinoma invasivo da mama tipicamente divide características imunofenotípicas com seu componente "in situ" de onde ele se originou. Assim um painel composto por receptores hormonais $(\mathrm{RH})$ negativos, citoqueratinas (CKs) basais e ou EGFR positivos, identificariam o carcinoma "in situ" basal- símile precursor do carcinoma invasor. Livasy e col em $2007^{(58)}$ completaram esta afirmação, mostrando que o componente "in situ" nestes tumores era observado com menos freqüência que o invasivo. Uma hipótese para este fato foi a provável rapidez de progressão para o componente invasor.

Observamos, pelo exposto, que entre os perfis geneticamente determinado por microarranjos de DNA e imunoistoquímico existe uma boa aproximação, embora comportem diferentes subtipos de importância prognóstica $^{(17 ; 18)}$.

Também nos fica claro que, além do padrão de expressão imunoistoquímica de receptores e HER2, o grau histológico é um dos mais importantes marcadores de diferenciação celular e fatores prognósticos. Neste contexto, neoplasias com padrão arquitetural sólido, indicativo de baixa diferenciação glandular, constituem um grupo heterogêneo, podendo corresponder a carcinomas luminais, HER2 ou basais, com implicações terapêuticas importantes. 
Neste sentido, nos propusemos a analisar o comportamento fenotípico morfológico e imunoistoquímico dos carcinomas mamários pouco diferenciados em nosso serviço quanto a freqüência dos diferentes perfis imunoistoquímicos básicos (RE, RP e HER2) e expressão de citoqueratinas basais (CK5, CK14 e CK17), citoqueratinas luminais (CK8/18) e de marcador relacionado ao controle do ciclo celular ( p63), oncoproteínas ( c-Kit e EGFR) e angiogênese (VEGF-A). 
2. Objetivos 
1. Determinar a freqüência dos perfis imunoistoquímicos básicos quanto à expressão de receptores hormonais e HER2 (luminal, HER2 e triplonegativo) entre carcinomas invasivos pouco diferenciados

2. Determinar diferenças quanto ao acometimento de pacientes jovens, características morfológicas e marcadores imunoistoquímicos dos subgrupos luminal, HER2, triplo-negativo e basal-símile 
3. Métodos 


\subsection{Certificação Institucional}

Este estudo foi aprovado pelo Comitê Científico do Departamento de Patologia da Faculdade de Medicina da Universidade de São Paulo e pela Comissão de Ética para Análise de Projetos de Pesquisa - CAPPesp da Diretoria Clínica do Hospital das Clínicas e da Faculdade de Medicina da Universidade de São Paulo. Por ser um estudo retrospectivo, não foi necessário o consentimento dos pacientes. No entanto, qualquer forma de identificação destes pacientes foi abolida, incluindo exclusão dos números de registro hospitalar e do anatomopatológico, assim que completado o banco de dados.

\subsection{Seleção dos casos}

Este estudo foi retrospectivo e iniciou com a seleção de carcinomas invasivos de mama graus 2 ou 3 pelo sistema de Nottingham (59) no período entre 2000 e 2003, nos arquivos da Divisão de Anatomia Patológica da Faculdade de Medicina da Universidade de São Paulo. Os critérios para inclusão no estudo foram: 
1) blocos existentes no arquivo

2) apresentação histológica predominantemente sólida, com menos de $10 \%$ de áreas com diferenciação tubular, correspondentes ao escore 3 do sistema de Ellis e Elston ${ }^{(59)}$

3) representação histológica de pelo menos um corte a cada centímetro no maior eixo do tamanho do tumor

Foram excluídos:

1) tipo histológico lobular

2) material com acentuado grau de autólise

Foram assim obtidos inicialmente 163 casos, todos previamente fixados em solução de formol tamponado a 10\% e incluídos em blocos de parafina segundo padronização do serviço. Um total de 29 casos foi excluído devido a: grau arquitetural menor que o reportado (5 casos), perda do bloco de parafina ( 2 casos), autólise (9 casos), material insuficiente (5 casos) e perda do material após a processamento complementar (preparo dos blocos de estudo) (8 casos). O total incluído de casos estudados foi 134.

\subsection{Exame anatomopatológico}

O tamanho dos tumores e extensão de acometimento linfonodal foram obtidos do laudo anatomopatológico original. 
As lâminas correspondentes aos casos foram revisadas e reclassificadas pela mesma patologista (RCMF) de acordo com os critérios de classificação da Organização Mundial de Saúde ${ }^{(60)}$.

Na revisão dos preparados foram avaliados: grau histológico segundo sistema de Nottingham ${ }^{(61)}$, grau nuclear, contagem mitótica (figuras em 10 campos microscópicos de 40 vezes com 0,5 mm de diâmetro), presença de necrose tumoral, presença de componente "in situ" e embolização vascular linfática $(E V L)$ peritumoral. Foram selecionadas duas áreas representativas de cada tumor para a construção do bloco de parafina pela técnica de arranjo em matriz de amostras teciduais (tissue microarray - TMA) e posterior análise imunoistoquímica.

A idade das pacientes, procedimento cirúrgico realizado, lateralidade, diagnóstico anatomopatológico, estadiamento e as características anatomopatológicas acima citadas foram incluídos em um banco de dados



\subsection{Construção do bloco pela técnica de arranjo em matriz de amostras teciduais (TMA)}

A construção do bloco de TMA foi realizada no Laboratório de Investigação Médica 14 (LIM14) da Faculdade de Medicina da Universidade de São Paulo. As áreas representativas de cada tumor identificadas nas lâminas coradas por hematoxilina-eosina foram marcadas nos blocos de 
parafina correspondentes. Com o objetivo de minimizar a perda das amostras no processamento do material e a heterogeneidade tumoral, dois cilindros (0,6 $\mathrm{mm}$ de diâmetro) foram extraídos das áreas selecionadas do bloco doador e transferidas para o bloco de parafina receptor com intervalos entre as amostra de $0,4 \mathrm{~mm}$, num sistema matricial no qual cada amostra tinha uma coordenada $(x, y)$ referencial, usando um instrumento de precisão para construção do TMA do fabricante Beecher Instruments, Sun Prairie, WI (Figura 1).

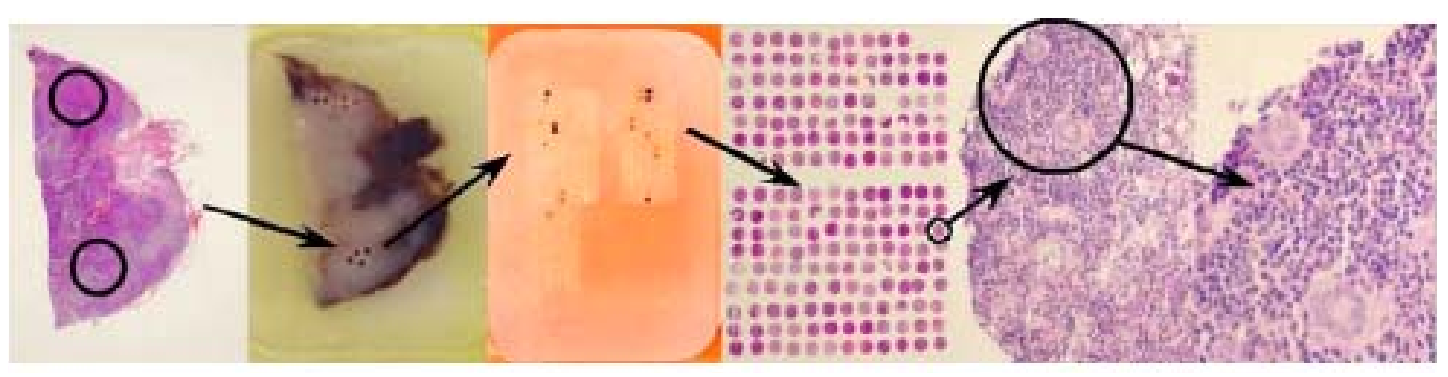

Figura 1 - Preparação do bloco de TMA

O bloco receptor foi composto por 284 amostras, que beneficiaram a análise e padronizaram condições experimentais. As amostras foram distribuídas em um arranjo matricial de 12 × 24, com 40 espaços em branco com mais 40 amostras de tecido pulmonar normal para orientação. Após a inserção das amostras no bloco receptor, este foi aquecido por 10 minutos na temperatura de $60^{\circ} \mathrm{C}$, e posteriormente cortados em fitas de $5 \mu \mathrm{m}$ no micrótomo do fabricante Leica Microsystems, Wetzlar, Germany, através do Sistema de Transferência de Cortes Histológicos por Selos (Instrumedics, Saint Louis, MO), com técnica padronizada (Figuras 2 e 3). 




Figura 2 - Sistema de transferência de cortes histológicos por selos

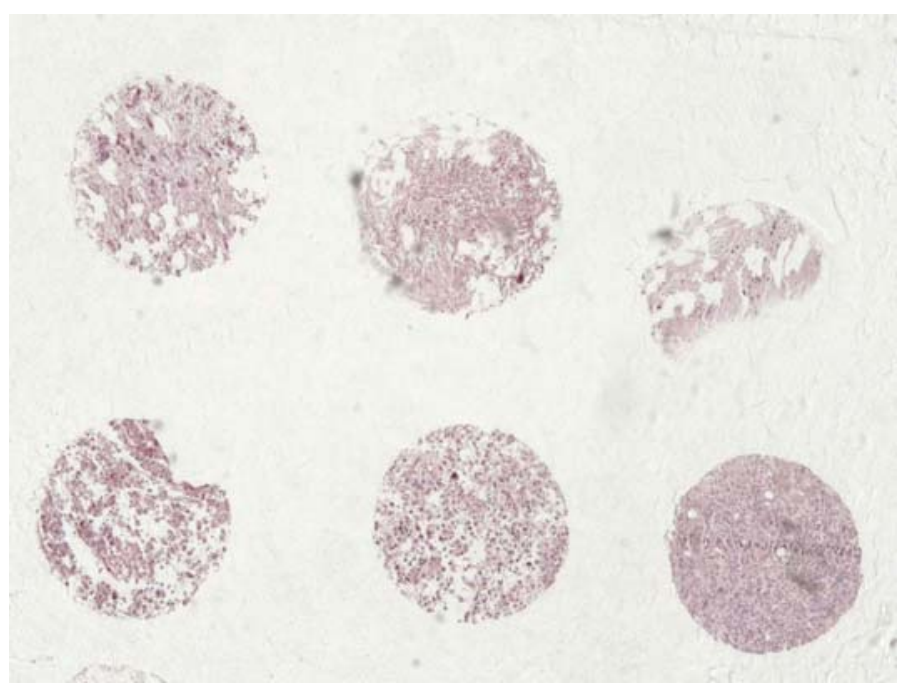

Figura 3 - Lâmina do TMA corada por hematoxilina-eozina (50X)

\subsection{Exame imunoistoquímico}

As expressões imunoistoquímicas de receptores de estrogênio (RE) e de progesterona (RP), HER2 e Ki67 foram avaliadas em cortes inteiros do tumor previamente realizados no mesmo serviço, segundo a mesma 
metodologia para todos os casos. As reações para as citoqueratinas (CK) basais (CK5, CK14 e CK17), receptor do fator de crescimento epidérmico (EGFR), c-Kit, p63, citoqueratinas luminais 8/18 e fator de crescimento endotelial vascular (VEGF-A) foram feitas nas lâminas provenientes do bloco receptor do TMA. O fabricante, código, clone, diluição, e pré-tratamento de cada anticorpo primário estão detalhados na Tabela 1.

Tabela 1 - Detalhes da metodologia das reações imunoistoquímicas

\begin{tabular}{|c|c|c|c|c|c|}
\hline Antígenos & Fabricante & Código & Clone & Diluição & Recuperação Antigênica \\
\hline RE & $\begin{array}{l}\text { Dako, } \\
\text { Carpinteria; CA }\end{array}$ & M 7047 & 1D5 & 1:2000 & $\begin{array}{l}\text { PP } 3.30 \text { MIN. Com Ác. } \\
\text { Cítrico } 10 \mathrm{mM} \text { PH } 6.0\end{array}$ \\
\hline $\mathrm{RP}$ & $\begin{array}{l}\text { Novocastra, } \\
\text { NewCastle, UK }\end{array}$ & PGR-312 & 16 & 1:1000 & $\begin{array}{l}\text { PP3.30 Min., com Ác. } \\
\text { Cítrico 10mM PH } 6.0\end{array}$ \\
\hline HER2 & $\begin{array}{l}\text { Dako, } \\
\text { Carpinteria; CA }\end{array}$ & A 0485 & policlonal & 1:2000 & $\begin{array}{l}\text { PP } 3.30 \mathrm{MIN} \text {, com Ác. } \\
\text { Cítrico } 10 \mathrm{mM}, \mathrm{PH} 6.0\end{array}$ \\
\hline Ki67 & $\begin{array}{l}\text { Dako, } \\
\text { Carpinteria; CA }\end{array}$ & M7187 & KI-S5 & $1: 600$ & $\begin{array}{l}\text { PP } 3.30 \text { MIN com Ác. } \\
\text { Cítrico 10mM PH6.0 }\end{array}$ \\
\hline EGFR & $\begin{array}{l}\text { Novocastra, } \\
\text { NewCastle, UK }\end{array}$ & $\begin{array}{l}\text { NCL- } \\
\text { EGFR-384 }\end{array}$ & EGFR.25 & $1: 100$ & $\begin{array}{l}\text { Pascal } 30 \text { sgundos, com } \\
\text { TRIS/EDTA, PH } 9.0\end{array}$ \\
\hline cKit & $\begin{array}{l}\text { Dako, } \\
\text { Carpinteria; CA }\end{array}$ & A4502 & policlonal & $1: 200$ & $\begin{array}{l}\text { Pascal } 30 \text { segundos, com } \\
\text { Ác.Cítrico } 10 \mathrm{mM} \text { PH6.0 }\end{array}$ \\
\hline p63 & $\begin{array}{l}\text { Dako, } \\
\text { Carpinteria; CA }\end{array}$ & M7247 & $4 \mathrm{~A} 4$ & $1: 500$ & $\begin{array}{l}\text { Pascal } 30 \text { segundos, com } \\
\text { Ác.Cítrico } 10 \mathrm{mM} \text { PH6.0 }\end{array}$ \\
\hline CK-14 & $\begin{array}{l}\text { Novocastra, } \\
\text { NewCastle, UK }\end{array}$ & $\begin{array}{l}\text { NCL-L- } \\
\text { LL002 }\end{array}$ & IL002 & $1: 50$ & $\begin{array}{l}\text { Pascal } 30 \text { segundos, com } \\
\text { Ác.Cítrico } 10 \mathrm{mM} \text { PH6.0 }\end{array}$ \\
\hline CK 8/18 & $\begin{array}{l}\text { Dako, } \\
\text { Carpinteria; CA }\end{array}$ & M631 & 35BH11 & $1: 400$ & $\begin{array}{l}\text { Pascal } 30 \text { segundos, com } \\
\text { Ác.Cítrico } 10 \mathrm{mM} \text { PH6.0 }\end{array}$ \\
\hline VEGF-A & $\begin{array}{l}\text { Santa Cruz } \\
\text { Biotechnology, } \\
\text { Santa Cruz, CA }\end{array}$ & SC-7269 & $\mathrm{C} 1$ & $1: 250$ & $\begin{array}{l}\text { Pascal } 40 \text { segundos, com } \\
\text { Ác. Cítrico } 10 \mathrm{mM} \text { PH6.0 }\end{array}$ \\
\hline CK5 & $\begin{array}{l}\text { Novocastra, } \\
\text { NewCastle, UK }\end{array}$ & NCL-CK5 & $\mathrm{XM}-26$ & $1: 200$ & $\begin{array}{l}\text { Pascal } 30 \text { segundos, com } \\
\text { Ác.Cítrico } 10 \mathrm{mM} \text { PH6.0 }\end{array}$ \\
\hline
\end{tabular}

Legendas: PP - panela de pressão; Ác. Cítrico - ácido cítrico;

TRIS/EDTA - Trishidroximetilaminometano/Ácido etilenodiamino tetra-acético;

CA - Califórnia; UK - United Kingdon 
As lâminas de TMA embebidas em parafina foram encubadas a temperatura de $60^{\circ} \mathrm{C}$ durante o período noturno, desparafinizadas com solução de xileno e re-hidratadas. A recuperação antigênica foi realizada antes de serem adicionados os anticorpos primários usando os protocolos otimizados. Os anticorpos primários foram diluídos em solução de albumina a $1 \%$ e incubados com as lâminas durante a noite a $4^{\circ} \mathrm{C}$. A revelação do anticorpo primário foi amplificada pela encubação das lâminas durante 30 minutos em temperatura de $37^{\circ} \mathrm{C}$ com o sistema de detecção designado Complexo Estreptavidina-Biotina-Peroxidase (Dako, código K-0492, Carpinteria, CA, diluição 1:200) para c-Kit, p63, CK14 e CK8/18. Para os RE e RP, HER2, Ki67 e EGFR o sistema de amplificação usado foi o LSAB(+) (Dako, código K0690, Carpinteria, CA, pronto para uso). Para CK5 e CK17, o sistema de amplificação usado foi o NovoLink (Novocastra, código RE7260K, Newcastle, UK, pronto para uso). E, finalmente para o VEGF-A, o sistema de amplificação usado foi o ABC elite (Vector Inc, código PK6100, Peterborough, UK, diluição: 3ml PBS para 1 gota de avidina e 1 gota de biotina).

Assim, as lâminas foram encubadas durante 5 minutos a $37^{\circ} \mathrm{C}$ em solução contendo 3\% de peróxido de hidrogênio e 3, 3'-diaminobenzidino, depois lavadas em água corrente e destilada, posteriormente coradas com hematoxilina, desidratadas com álcool, passadas em xilol e finalmente montadas com entelan e lamínula. 


\subsection{Interpretação das reações imunoistoquímicas}

As reações foram interpretadas como positivas baseadas na marcação nuclear para RE, RP, Ki67 e p63 (Figura 4A-D); na marcação de membrana para HER2 e EGFR (Figura 5A e B), e citoplasmática para CK5, CK14, CK17, CK8/18, c-Kit e VEGF-A (Figura 6A-F). A intensidade da coloração não foi considerada, entretanto, somente casos com pelo menos moderada intensidade foi considerado positivo. 


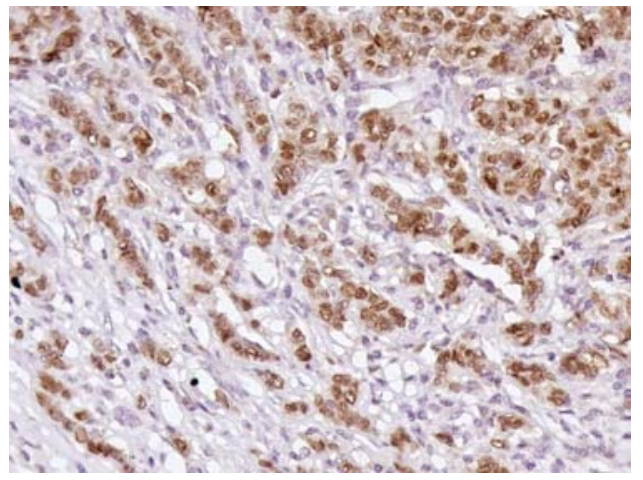

Figura 4A - Marcação nuclear para receptor de estrogênio (400X)

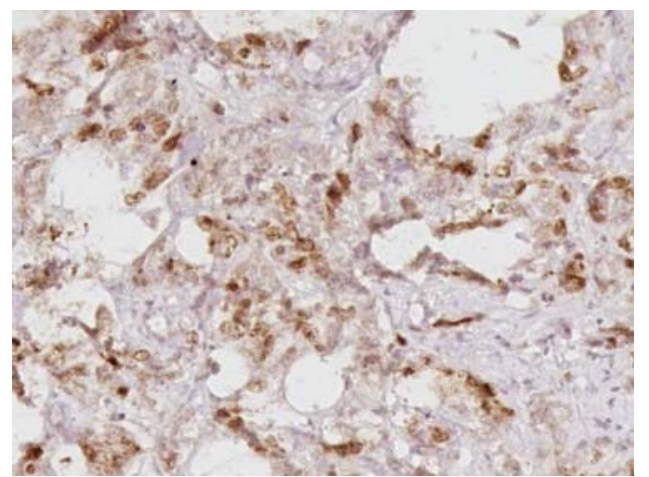

Figura 4C - Marcação nuclear para Ki67 (400X)

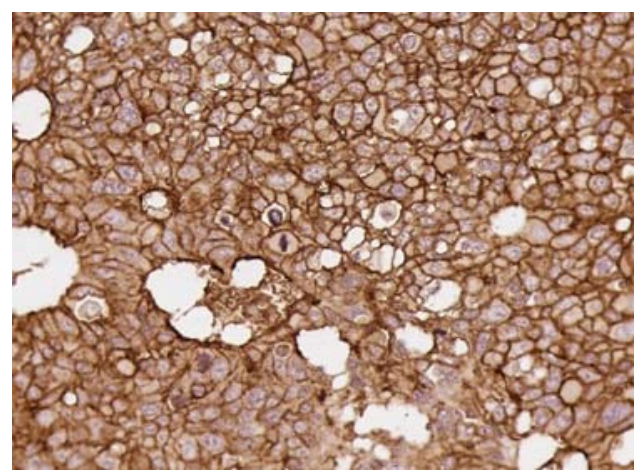

Figura 5A - Marcação de membrana $3+/ 3+$ para HER2 (400X)

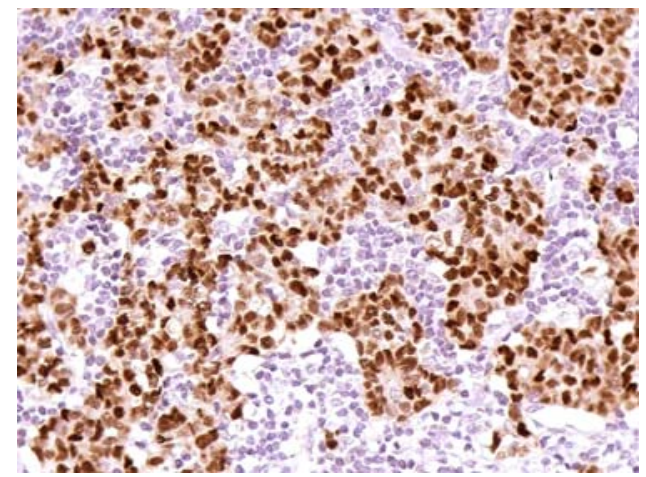

Figura 4B - Marcação nuclear para receptor de progesterona (400X)

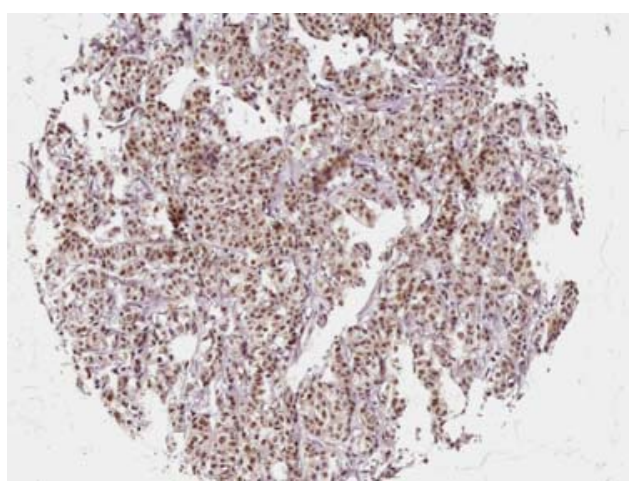

Figura 4D - Marcação nuclear para p63 (200X)

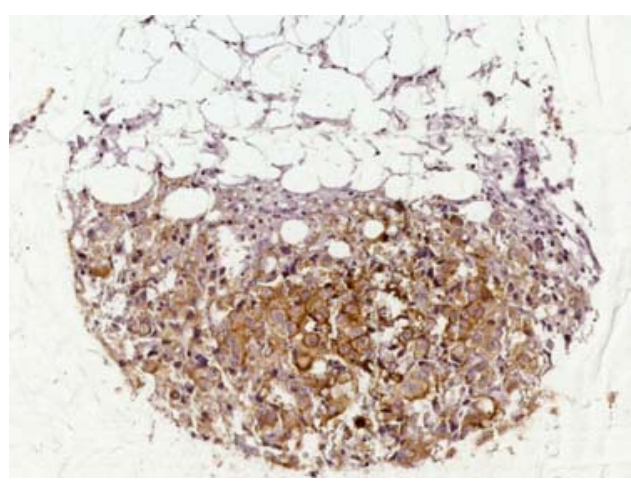

Figura 5B - Marcação de membrana para EGFR (200X) 


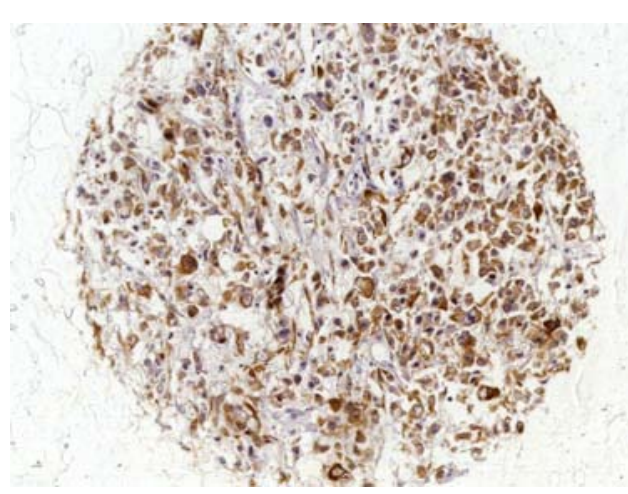

Figura 6A - Marcação citoplasmática para CK5 (200X)

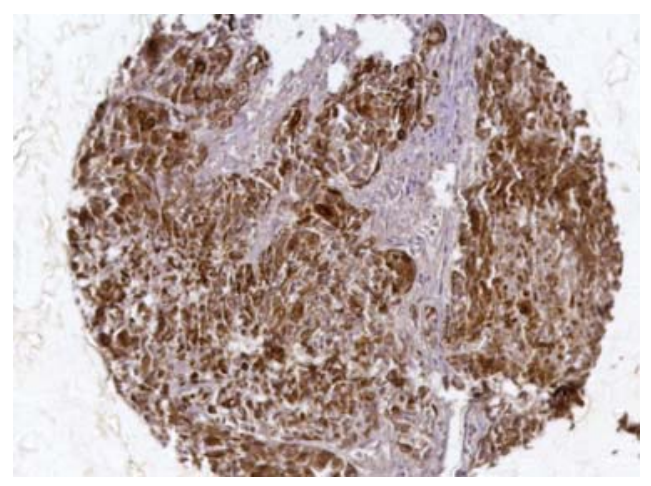

Figura 6C - Marcação citoplasmática para CK17 (200X)

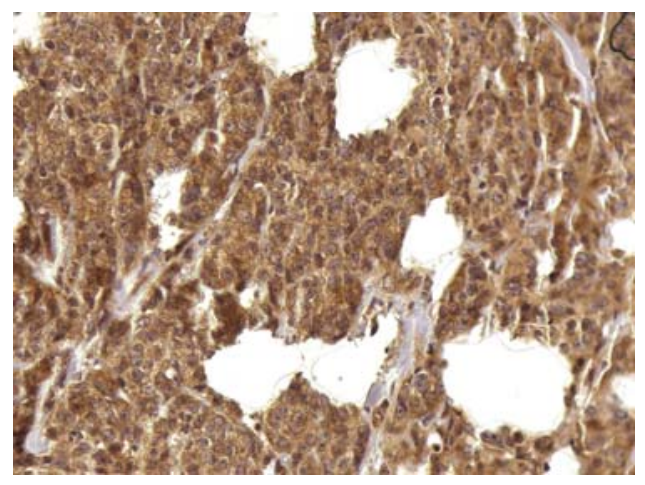

Figura 6E - Marcação citoplasmática para c-Kit (400X)

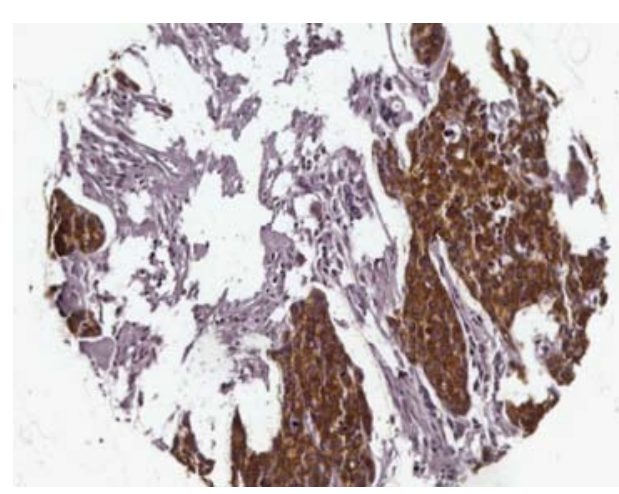

Figura 6B - Marcação citoplasmática para CK14 (200X)

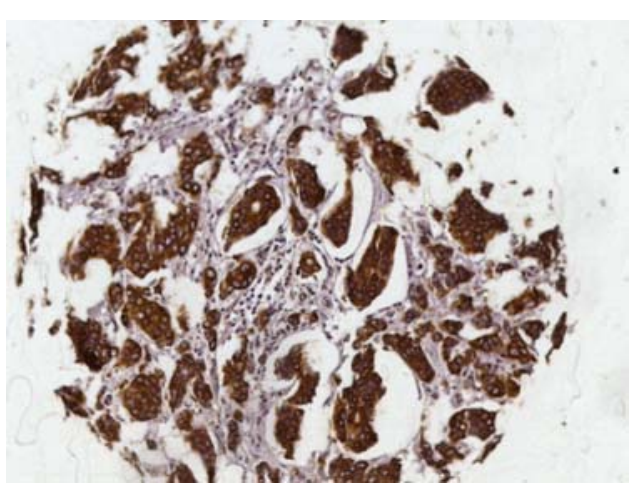

Figura 6D - Marcação citoplasmática para CK8/18 (200X)

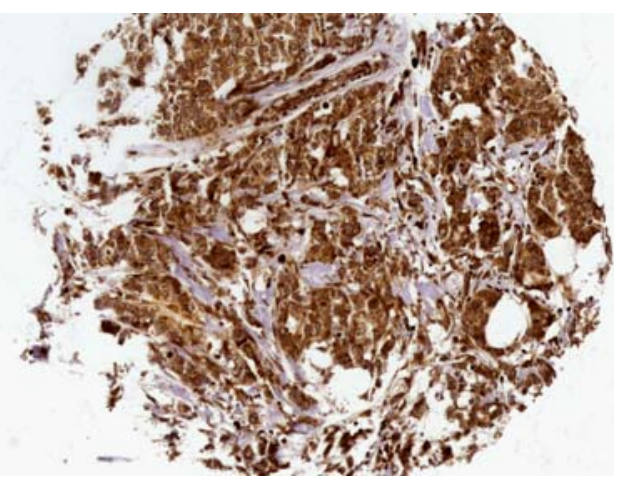

Figura 6F - Marcação citoplasmática para VEGF-A (200X) 
Aproximadamente 60 lâminas de TMA foram preparadas e coradas com hematoxilina-eosina a cada intervalo de 15 lâminas (com exceção da primeira, que foi corada no intervalo 10), para selecionar o intervalo (entre lâminas 11 e 40), e então enviados para a leitura, interpretação e cadastro dos resultados. Controles positivos para cada marcador foi usado de acordo com a bula do fabricante.

Para os marcadores RE, RP, CK5, CK14, CK17, CK8/18, EGFR, c-Kit, p63 e VEGF-A as reações foram interpretadas como positivas se pelo menos $1 \%$ das células tumorais invasivas apresentaram coloração. Para o HER-2 foram considerados positivos somente os casos escore $3+$, segundo critérios recomendados pelas ASCO/CAP (6). A expressão de citoqueratinas basais foi considerada positiva quando pelo um dos marcadores (CK5, 14, 17) foi positivo. O status do receptor hormonal foi considerado positivo se a marcação foi positiva para pelo menos um dos receptores. A expressão do Ki67 foi agrupada em escores, segundo a proporção de células positivas: 0-25\% 25-50\%, 51-75\% e>75\%, com o valor de corte de 50\% (anexo A).

\subsection{Análise estatística}

A análise estatística foi feita baseada nos softwares SPSS, versão 10.0.5 (SPSS Inc, Chicago, IL) e StatXact, versão 4.0.1 (Cytel Software Corporation, Cambridge, MA). 
Estatísticas descritivas foram aplicadas para apresentação dos resultados referentes a idade das pacientes, tamanho dos tumores, características histológicas e expressão dos diferentes marcadores imunoistoquímicos.

As correlações entre as variáveis categóricas foram determinadas pelo teste de Pearson $\mathrm{x} 2$ e o teste exato de Fisher.

Para as análises multivariadas, as variáveis que demonstraram correlações estatísticas com o grupo triplo-negativo [RE, RP e HER2 (-)] e com o grupo das citoqueratinas basais positivas na análise univariada (significância estatística definida por $\mathrm{P} \leq 0,05)$ foram analisadas através da regressão logística binária usando o método "forward stepwise". Para as comparações múltiplas, nós usamos o valor de $P$ ajustado $(P \leq 0,009)$, calculado pela fórmula: $\mathrm{P}_{\text {ajustado }} \leq 1-\sqrt[n]{1-\alpha}$, onde $\mathrm{n}=$ número de comparações ( $n=6$ comparações) e $\alpha=0,05^{(62)}$. 
4. Resultados 
Foram estudados 134 carcinomas de mama procedentes de 134 pacientes com idade entre 21 a 94 anos (média $=57,5$ e mediana $=$ $55,1 \pm 14,4$ anos), 20 destas com 40 anos ou menos (14,9\%). O tamanho dos tumores variou de $0,5 \mathrm{~cm}$ a $16,0 \mathrm{~cm}$ (média $=4,68$, desvio padrão $=3,49$ e mediana $=3,5), 84(72,41 . \%)$ tinham mais de $2,0 \mathrm{~cm}$. Quanto à lateralidade, 56 casos (41,8\%) localizaram-se na mama direita e 67 (50\%) na mama esquerda; em 11 casos (8,2\%) esta informação não foi cadastrada. A axila foi estudada em 117 casos e esteve positiva em 83 (70,9 \%) casos. Histologicamente, os tumores foram classificados como: 124 (92,5\%) carcinoma ductal invasivo SOE, $2(1,4 \%)$ carcinoma apócrino invasivo, 4 (3\%)carcinoma invasivo com características lobulares, 3 (2,2\%) carcinoma metaplásico e 1 carcinoma mucinoso invasivo (0,7\%). Dos 134 casos, 25 foram classificados como grau histológico $2(18,6 \%)$ e 109 como grau 3 (81,4\%). A média de idade dos pacientes com tumores grau 2 e 3 foi 58,08 anos e 55,35 anos, respectivamente.

Segundo a expressão dos $\mathrm{RH}, 73$ tumores $(54,5 \%)$ eram $\mathrm{RH}(+)$, $61(45,5 \%)$ eram $\mathrm{RH}(-)$. Quarenta e oito $(35,8 \%)$ tumores eram HER2(+). De acordo com estes marcadores imunoistoquímicos, dividimos os pacientes em 3 subgrupos: subgrupo imunoistoquímico luminal: $\mathrm{RH}(+)$, independente da expressão de HER2 (73 casos ou 54,5\%), subgrupo imunoistoquímico HER2: HER2(+) e RH(-) (22 casos ou 16,4\%) e subgrupo imunoistoquímico triplo-negativo: $\mathrm{RH}(-)$ e HER2(-) (39 casos ou 29,1\%). Os achados clínicopatológicos de cada grupo estão ilustrados na tabela 2. 
Tabela 2 - Características clínico-patológicas dos carcinomas de mama de acordo com os perfis imunoistoquímicos básicos

\begin{tabular}{|c|c|c|c|c|}
\hline & $\begin{array}{c}\text { RH (-) } \\
\text { HER2 (-) } \\
\text { N (\%) }\end{array}$ & $\begin{array}{c}\text { RH (-) } \\
\text { HER2 (+) } \\
\text { N (\%) }\end{array}$ & $\begin{array}{l}\text { RH (+) } \\
\text { N (\%) }\end{array}$ & $\mathbf{P t}$ \\
\hline Idade $\leq 40$ anos & $6 / 38(15,8)$ & $3 / 22(13,6)$ & $11 / 72(15,3)$ & 0,974 \\
\hline $\mathrm{T}>2,0 \mathrm{~cm}$ & $31 / 34(91,2)$ & $14 / 20(70,0)$ & $39 / 62(62,9)$ & 0,012 \\
\hline Componente de CDIS & $12 / 39(30,8)$ & $15 / 22(68,2)$ & $43 / 73(58,9)$ & 0,005 \\
\hline $\mathrm{pN}(+)$ & $22 / 34(64,7)$ & $15 / 20(75,0)$ & $46 / 64(71,9)$ & 0,671 \\
\hline Necrose & $33 / 39(84,6)$ & $16 / 22(72,7)$ & $43 / 73(58,9)$ & 0,018 \\
\hline Contagem mitótica escore 3 & $17 / 39(43,6)$ & $11 / 22(50,0)$ & $16 / 73(21,9)$ & 0,012 \\
\hline Grau nuclear 3 & $36 / 39(92,3)$ & $18 / 22(81,8)$ & $55 / 73(75,3)$ & 0,090 \\
\hline EVL & $12 / 39(30,8)$ & $13 / 22(59,1)$ & $22 / 73(30,1)$ & 0,036 \\
\hline Ki-67 > 50\% & $20 / 39(51,3)$ & $12 / 22(54,5)$ & $11 / 73(15,1)$ & $<0,0001$ \\
\hline p 63 & $3 / 37(8,1)$ & $0 / 21(0)$ & $2 / 69(2,9)$ & 0,252 \\
\hline Citoqueratinas basais & $29 / 39(74,4)$ & $6 / 22(27,3)$ & $18 / 73(24,7)$ & $<0,0001$ \\
\hline VEGF-A & $19 / 39(48,7)$ & $10 / 20(50,0)$ & $40 / 68(58,8)$ & 0,549 \\
\hline EGFR & $3 / 38(7,9)$ & $1 / 22(4,5)$ & $0 / 69(0)$ & 0,072 \\
\hline c-Kit & $7 / 38(18,4)$ & $1 / 22(4,5)$ & $7 / 69(10,1)$ & 0,231 \\
\hline CK8/18 & $13 / 38(34,2)$ & $8 / 20(40)$ & $42 / 68(61,8)$ & 0,015 \\
\hline
\end{tabular}

† Teste de Qui-Quadrado de Pearson, Nível de significância $\rightarrow \mathrm{P}<0,05$

Os três subgrupos foram semelhantes à fração de pacientes jovens $(p=0,974)$, ao acometimento de linfonodos axilares $(p=0,671)$ e ao número de casos grau 3 nuclear $(p=0,090)$. Também não tiveram diferenças quanto à expressão de $p 63(p=0,252)$, VEGF-A $(p=0,549)$, EGFR $(p=0,072)$ e c-Kit $(p=0,231)$. 
O subgrupo triplo-negativo apresentou a maior proporção de tumores maiores que $2,0 \mathrm{~cm}(91,2 \%)$, maior freqüência de necrose $(84,6 \%)$ e a maior taxa de expressão de citoqueratinas basais $(74,4 \%)$. Este subgrupo juntamente com o subgrupo HER2 expressou maiores índices de proliferação medidos tanto pelo Ki67 >50\% (51,3\% e 54,5\%, respectivamente), quanto pela contagem mitótica escore $3(43,6 \%$ e $50,0 \%$, respectivamente). O subgrupo HER2 também mostrou maior número de casos associados à presença de componente "in situ" $(68,2 \%)$ e maior freqüência de detecções de EVL (59,1\%). O subgrupo luminal apresentou o maior número de casos com expressão de citoqueratinas luminais $8 / 18(61,8 \%)$ e o menor número de tumores maiores que $2,0 \mathrm{~cm}(62,9 \%)$ (tabela 3$)$.

Na tabela 3 observa-se a comparação entre os subgrupos:

\begin{tabular}{|c|c|c|c|c|c|c|}
\hline & $\begin{array}{c}\text { RE/RP (-) } \\
\text { HER2 (-) } \\
\text { vs } \\
\text { RE/RP (-) } \\
\text { HER2 (+) }\end{array}$ & $\begin{array}{c}\text { RE/RP (-) } \\
\text { HER2 (-) } \\
\text { vs } \\
\text { RE/RP (+) } \\
\text { HER2 (-) }\end{array}$ & $\begin{array}{c}\text { RE/RP (-) } \\
\text { HER2 (-) } \\
\text { vs } \\
\text { RE/RP (+) } \\
\text { HER2 (+) }\end{array}$ & $\begin{array}{c}\text { RE/RP (-) } \\
\text { HER2 (+) } \\
\text { vs } \\
\text { RE/RP (+) } \\
\text { HER2 (-) }\end{array}$ & $\begin{array}{c}\text { RE/RP (-) } \\
\text { HER2 (+) } \\
\text { vs } \\
\text { RE/RP (+) } \\
\text { HER2 (+) }\end{array}$ & $\begin{array}{c}\text { RE/RP (+) } \\
\text { HER2 (-) } \\
\text { vs } \\
\text { RE/RP (+) } \\
\text { HER2 (+) }\end{array}$ \\
\hline $\mathrm{T}$ & 0,0625 & 0,0007 & 0,2408 & 0,4022 & 0,7298 & 0,1041 \\
\hline CDIS & 0,0071 & 0,0296 & 0,0103 & 0,4311 & 1,000 & 0,4628 \\
\hline Necrose & 0,3218 & 0,0090 & 0,0436 & 0,2901 & 0,5421 & 0,8069 \\
\hline Contagem mitótica escore 3 & 0,7897 & 0,0646 & 0,0612 & 0,0505 & 0,0337 & 0,7739 \\
\hline EVL+ & 0,0565 & 0,6349 & 0,5970 & 0,0143 & 0,2461 & 0,2926 \\
\hline Ki67 & 1,0000 & 0,0027 & 0,0004 & 0,0048 & 0,0005 & 0,3075 \\
\hline Citoqueratinas Basais & 0,0005 & $<0,0001$ & 0,0008 & 0,7603 & 1,0000 & 0,4046 \\
\hline CK 8-18 & 0,7758 & 0,0041 & 0,2797 & 0,0563 & 0,5512 & 0,1912 \\
\hline
\end{tabular}

Teste Exato de Fisher, Nível de significância $\rightarrow P<0,009$ 
A comparação entre os carcinomas triplo-negativos e os carcinomas luminais sem expressão de HER2, mostrou que os primeiros mais freqüentemente são maiores do que $2,0 \mathrm{~cm} \quad(p=0,0007)$, alta atividade proliferativa medidos pelo Ki-67>50\% ( $p=0,027)$, apresentam expressão de CK basais $(p<0,0001)$ e menor freqüência de CK luminais $(p=0,0041)$.

A presença de Carcinoma Ductal "in situ" (CDIS) foi menor nos carcinomas triplo-negativos do que no grupo $\mathrm{RH}(-) / \mathrm{HER}(+)$. Já a atividade proliferativa avaliada pela expressão do Ki-67>50\% permitiu observar diferenças entre os subgrupos triplo-negativos e $\mathrm{RH}(+)$ e entre os HER2(+) e $\mathrm{RH}(+)$.

Comparando os subgrupos triplo-negativos e HER2, as únicas diferenças estatisticamente significantes foram a presenças de CDIS no subgrupo HER2 $(p=0,0071)$ e a expressão de CK basais maior no subgrupo triplo-negativo $(p=0,0005)$.

Nenhuma das variáveis mostrou diferença estatística entre os subgrupos luminais quanto à expressão ou não de HER2.

A comparação entre os carcinomas HER2(+) quanto à expressão de $\mathrm{RH}$ mostrou maiores indicadores de atividade proliferativa medidos pelo Ki-67>50\% no grupo RH(-).

Quanto à expressão de citoqueratinas basais, 81 casos $(60,44 \%)$ não expressaram citoqueratina alguma e 53 (39,56\%) expressaram pelo menos uma. O subgrupo triplo-negativo foi o que teve a maior expressão de citoqueratinas basais (tabela 4). 
Tabela 4 - Grupos triplo-negativo e não triplo-negativo e suas relações com múltiplas variáveis clínica-patológicas

\begin{tabular}{lccc}
\hline & $\begin{array}{c}\text { Triplo-negativo } \\
\mathbf{N}(\%)\end{array}$ & $\begin{array}{c}\text { Não Triplo- } \\
\text { negativo } \\
\mathbf{N}(\%)\end{array}$ & $\mathbf{P \dagger}$ \\
\hline Idade $\leq 40$ anos & $6 / 38(15,8)$ & $14 / 94(14,9)$ & 1,0000 \\
\hline T > 2,0cm & $31 / 34(91,2)$ & $53 / 82(64,6)$ & $\mathbf{0 , 0 0 3 0}$ \\
\hline Componente de CDIS & $12 / 39(30,8)$ & $58 / 95(61,1)$ & $\mathbf{0 , 0 0 2 1}$ \\
\hline pN(+) & $22 / 34(64,7)$ & $61 / 84(72,6)$ & 0,5047 \\
\hline Necrose & $33 / 39(84,6)$ & $59 / 95(62,1)$ & $\mathbf{0 , 0 1 3 4}$ \\
\hline Contagem mitótica escore 3 & $17 / 39(43,6)$ & $27 / 95(28,4)$ & 0,1068 \\
\hline Grau nuclear 3 & $39 / 39(100,0)$ & $91 / 95(95,8)$ & 0,3219 \\
\hline EVL & $12 / 39(30,8)$ & $35 / 95(36,8)$ & 0,5547 \\
\hline Ki-67>50\% & $20 / 39(51,3)$ & $23 / 95(24,2)$ & $\mathbf{0 , 0 0 4 0}$ \\
\hline p63 & $3 / 37(8,1)$ & $2 / 90(2,2)$ & 0,1475 \\
\hline Citoqueratinas basais & $29 / 39(74,4)$ & $24 / 95(25,3)$ & $<0,0001$ \\
\hline VEGF-A & $19 / 39(48,7)$ & $50 / 88(56,8)$ & 0,443 \\
\hline EGFR & $3 / 38(7,9)$ & $1 / 91(1,1)$ & 0,076 \\
\hline cKIT & $13 / 38(34,2)$ & $50 / 88(56,8)$ & $\mathbf{0 , 0 3 2}$ \\
\hline & & $8 / 91(8,8)$ & 0,138 \\
\hline CK8/18 & $18,4)$ & & \\
\hline
\end{tabular}

†Teste Exato de Fisher, Nível de significância $\rightarrow \mathrm{P}<0,05$

As características clínico-patológicas de acordo com a expressão de citoqueratinas basais podem ser observadas na tabela 5. O grupo citoqueratinas basais positivas apresentou a maior proporção de pacientes com $\leq 40$ anos ( $25 \%$ vs. $8,8 \%$ ); maior número de casos com tumores $>2 \mathrm{~cm}$ 
( $83,3 \%$ vs. $64,7 \%)$ e com necrose $(81,1 \%$ vs. $60,6 \%)$ além de maiores valores de Ki67>50\% (47,2\% vs.22,2\%) e menor expressão de CK luminais (60,0\% vs. $35,3 \%$ ). A maior diferença entre estes grupos foi o fenótipo triplonegativo, mais freqüente no grupo que expressou as citoqueratinas basais (54,7\% vs. $12,3 \%)$. Não houve diferença para os marcadores p63, VEGF-A, EGFR e c Kit nestes dois subgrupos citados (tabela 5).

Tabela 5 - Citoqueratinas basais e suas relações com as múltiplas variáveis clínica-patológicas

\begin{tabular}{lccc}
\hline & $\begin{array}{c}\text { Ausência de } \\
\text { expressão das } \\
\text { citoqueratinas } \\
\text { basais } \\
\mathbf{N}(\%)\end{array}$ & $\begin{array}{c}\text { Expressão das } \\
\text { citoqueratinas } \\
\text { basais }\end{array}$ & P† \\
\hline Idade $\leq 40$ anos & $7 / 80(8,8)$ & $13 / 52(25,0)$ & $\mathbf{0 , 0 1 3 8}$ \\
\hline T > 2,0 cm & $44 / 68(64,7)$ & $40 / 48(83,3)$ & $\mathbf{0 , 0 3 4 9}$ \\
\hline Componente de CDIS & $46 / 81(56,8)$ & $24 / 53(45,3)$ & 0,2183 \\
\hline pN(+) & $51 / 69(73,9)$ & $32 / 49(65,3)$ & 0,4136 \\
\hline Necrose & $49 / 81(60,6)$ & $43 / 53(81,1)$ & $\mathbf{0 , 0 1 3 6}$ \\
\hline Contagem mitótica escore 3 & $22 / 81(27,2)$ & $22 / 53(41,5)$ & 0,935 \\
\hline Grau nuclear 3 & $77 / 81(95,1)$ & $53 / 53(100,0)$ & 0,1524 \\
\hline EVL & $28 / 81(34,6)$ & $19 / 53(35,8)$ & 1,0000 \\
\hline Ki-67>50\% & $18 / 81(22,2)$ & $25 / 53(47,2)$ & $\mathbf{0 , 0 0 4 2}$ \\
\hline p63 & $2 / 76(2,6)$ & $3 / 51(5,9)$ & 0,3901 \\
\hline RE/RP (-) HER2 (-) & $10 / 81(12,3)$ & $29 / 53(54,7)$ & $<0,0001$ \\
\hline VEGF-A & $42 / 75(56,0)$ & $27 / 52(51,9)$ & 0,718 \\
\hline EGFR & $2 / 77(2,6)$ & $2 / 52(3,8)$ & 1,000 \\
\hline cKit & $6 / 77(7,8)$ & $9 / 52(17,3)$ & 0,160 \\
\hline CK8/18 & $45 / 75(60,0)$ & $18 / 51(35,3)$ & $\mathbf{0 , 0 1 1}$ \\
\hline & & & \\
\hline Teste Exato de Fs & & \\
\hline
\end{tabular}

†Teste Exato de Fisher, Nível de significância $\rightarrow \mathrm{P}<0,05$ 
Além da maior expressão de CKs basais, o subgrupo triplo-negativo apresentou com maior freqüência tumores > $2 \mathrm{~cm}(91,2 \%$ vs.64,6\%), maiores taxas de necrose (84,6 vs. 62,1$)$, maior freqüência de grau nuclear 3 (92,3\% vs. $76,8 \%)$ e maior atividade proliferativa indicada pelo Ki67 $>50 \%$ (51,3\% vs.24,2\%) do que o subgrupo não triplo-negativo (tabela 4 ).

Nas análises multivariadas, entre os carcinomas pouco diferenciados, o fator preditivo independente associado ao perfil triplo-negativo foi a expressão de citoqueratinas basais $(p<0.0001)$ (tabela 6$)$.

Tabela 6 - Regressão Logística Binária - Fatores preditivos independentes dos tumores triplo-negativos

\begin{tabular}{lcccc}
\hline Variável & $\boldsymbol{\beta}$ & $\begin{array}{c}\text { Odds Ratio } \\
\left(\mathbf{e}^{\boldsymbol{\beta}}\right)\end{array}$ & $\mathbf{9 5 , 0} \% \mathbf{C l}$ & $\mathbf{p}$ \\
\hline Citoqueratinas Basais & & & & \\
\hline Negativo & 0 & 1 & & \\
\hline Positivo & 2,145 & 8,538 & $3,194-22,825$ & $<\mathbf{0 , 0 0 0 1}$ \\
\hline & & & & \\
\hline Constante & $-1,419$ & & & \\
\hline
\end{tabular}


O fator preditivo independente associado à expressão de citoqueratinas basais foi a presença do fenótipo triplo-negativo $(p<0,0001)$ (tabela 7).

Tabela 7 - Regressão Logística Binária - Fatores preditivos independentes da expressão de citoqueratinas basais

\begin{tabular}{lcccc}
\hline Variável & $\boldsymbol{\beta}$ & Odds Ratio $\left(\mathbf{e}^{\boldsymbol{\beta}}\right)$ & $\mathbf{9 5 , 0} \% \mathbf{C l}$ & $\mathbf{p}$ \\
\hline Triplo-Negativo & & & & \\
\hline Não & 0 & 1 & & \\
\hline Sim & 2,198 & 9,011 & $3,447-23,355$ & $<0,0001$ \\
\hline & & & & \\
\hline Constante & $-1,497$ & & & \\
\hline
\end{tabular}

$\mathrm{Na}$ tabela 8, ilustramos as características clínico-patológicas comparativas entre carcinomas com perfil imunoistoquímico basal-símile correspondente aos tumores triplo-negativo com expressão de pelo menos uma das CK basais e os demais subgrupos. 
Tabela 8 - Características clínico-patológicas comparativas entre carcinomas com perfil imunoistoquímico basal-símile (triplo-negativo e CK basal) e os demais subgrupos

\begin{tabular}{|c|c|c|c|c|c|}
\hline Característica & $\begin{array}{c}\text { Triplo- } \\
\text { negativo } \\
\text { Basal-símile }\end{array}$ & $\begin{array}{l}\text { Triplo-negativo } \\
\text { não basal- } \\
\text { símile }\end{array}$ & $\begin{array}{c}\text { RH(-) } \\
\text { HER2 (+) }\end{array}$ & RH (+) & $\mathbf{P}$ \\
\hline Idade $\leq 40$ anos & $6 / 29(20,7 \%)$ & 0 & $3 / 22(13,6 \%)$ & $11 / 72(15,3 \%)$ & 0.4966 \\
\hline $\mathrm{T}>2,0 \mathrm{~cm}$ & $25 / 26(96,2 \%)$ & $6 / 8(75,0 \%)$ & $14 / 20(70,0 \%)$ & $39 / 62(62,9 \%)$ & 0.0158 \\
\hline $\begin{array}{l}\text { Componente de } \\
\text { CDIS }\end{array}$ & $10 / 29(34,48 \%)$ & $2 / 10(20 \%)$ & $15 / 22(68,2 \%)$ & $43 / 73(58,9 \%)$ & 0.0085 \\
\hline $\mathrm{pN}(+)$ & $16 / 28(57,1 \%)$ & $5 / 10(50,0 \%)$ & $15 / 20(75 \%)$ & $46 / 64(71,9 \%)$ & 0.7495 \\
\hline Necrose & $25 / 29(86,2 \%)$ & $8 / 10(80,0 \%)$ & $16 / 22(72,7 \%)$ & $43 / 73(58,9 \%)$ & 0.0407 \\
\hline $\begin{array}{l}\text { Contagem } \\
\text { mitótica } \\
\text { escore } 3\end{array}$ & $13 / 29(44,8 \%)$ & $4 / 10(40,0 \%)$ & $11 / 22(50,0 \%)$ & $16 / 73(21,9 \%)$ & 0.0276 \\
\hline Grau nuclear 3 & $29 / 29(100 \%)$ & 10/10 (100\%) & 22/22 (100\%) & $69 / 73(94,52 \%)$ & 0.3479 \\
\hline EVL & $10 / 29(34,5 \%)$ & $2 / 10(20 \%)$ & $13 / 22(59,1 \%)$ & $22 / 73(30,1 \%)$ & 0.0602 \\
\hline
\end{tabular}

${ }^{\dagger}$ Teste de Qui-Quadrado de Pearson, Nível de significância $\rightarrow \mathrm{P}<0,05$

O subgrupo basal-símile mostrou a maior freqüência de tumores > 2,0 cm $(96,2 \%)$ e conjuntamente com o subgrupo triplo-negativo não basalsímile, a maior freqüência de tumores com presença de necrose $(86,2 \%$ e $80,0 \%$, respectivamente) e com contagem mitótica escore 3 (44,8\% e 40,0\%, respectivamente). O subgrupo HER2 mostrou a maior freqüência de componente "in situ" associado (68,2\%). A comparação múltipla entre os grupos está na tabela 9. 
Tabela 9 - Comparação múltipla entre os subgrupos

\begin{tabular}{|c|c|c|c|c|c|c|}
\hline & $\begin{array}{c}\text { Triplo- } \\
\text { negativo } \\
\text { Basal- } \\
\text { símile } \\
\text { vs } \\
\text { Triplo- } \\
\text { negativo } \\
\text { Não Basal- } \\
\text { símile }\end{array}$ & $\begin{array}{c}\text { Triplo- } \\
\text { negativo } \\
\text { Basal- } \\
\text { símile } \\
\text { vs } \\
\text { RH(-) } \\
\text { HER2 (+) }\end{array}$ & $\begin{array}{c}\text { Triplo- } \\
\text { negativo } \\
\text { Basal- } \\
\text { símile } \\
\text { vs } \\
\text { RH (+) }\end{array}$ & $\begin{array}{c}\text { Triplo- } \\
\text { negativo } \\
\text { Não } \\
\text { Basal- } \\
\text { símile } \\
\text { vs } \\
\text { RH (-) } \\
\text { HER2 (+) }\end{array}$ & $\begin{array}{c}\text { Triplo- } \\
\text { negativo } \\
\text { Não } \\
\text { Basal- } \\
\text { símile } \\
\text { vs } \\
\text { RH (+) }\end{array}$ & $\begin{array}{c}\text { RH(-) } \\
\text { HER2 (+) } \\
\text { vs } \\
\text { RH (+) }\end{array}$ \\
\hline $\mathrm{T}>2,0 \mathrm{~cm}$ & 0,1310 & 0,0326 & 0,0012 & 1,0000 & 0,7023 & 0,6041 \\
\hline $\begin{array}{l}\text { Componente de } \\
\text { CDIS }\end{array}$ & 0,6927 & 0,0245 & 0,0300 & 0,0209 & 0,0383 & 0,4675 \\
\hline Necrose & 0,6360 & 0,2952 & 0,0100 & 1,0000 & 0,3032 & 0,3185 \\
\hline $\begin{array}{l}\text { Contagem mitótica } \\
\text { escore } 3\end{array}$ & 1,0000 & 0,7816 & 0,0286 & 0,7120 & 0,2436 & 0,0154 \\
\hline
\end{tabular}

Teste Exato de Fisher, Nível de significância $\rightarrow P<0,009$

O subgrupo basal-símile não foi diferente em relação aos carcinomas triplo-negativos não basal-símile segundo as variáveis estudadas, mas mostrou diferença com os carcinomas de fenótipo luminal em relação ao tamanho do tumor (tabela 9). Tumores grandes foram mais freqüentes entre o subgrupo basal-símile quando comparado aos luminais. 


\section{Discussão}


É fascinante estudar os carcinomas mamários. Há bem pouco tempo, conhecíamos não mais que 10 subtipos deles; no entanto hoje, com o advento dos estudos genéticos não temos idéia quantos são, dada a grande heterogeneidade desta doença.

Cientes da importância do grau histológico como discriminador prognóstico, iniciamos nosso estudo selecionando apenas os carcinomas de mama pouco diferenciados segundo critérios arquiteturais, ou seja, aqueles sólidos ou com menos de 10\% formação tubular, com grande probabilidade de ser associado a perfil prognóstico desfavorável, incluindo o fenótipo basal-símile (Figura 7A - C). 




Figura 7A - Carcinoma pouco

diferenciado de mama com padrão arquitetural sólido (HE 200X)

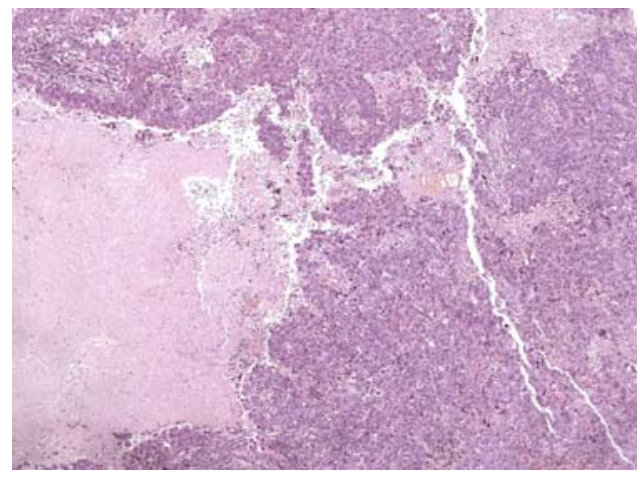

Figura 7B - Carcinoma pouco diferenciado de mama com extensas áreas de necrose de padrão geográfico (HE 100X)



Figura 7C - Carcinoma pouco diferenciado de mama com bordas expansivas e resposta linfocítica estromal periférica (HE 100X)

Neste trabalho, nós analisamos apenas características morfológicas e imunoistoquímicas. É preciso ressaltar que embora não haja correspondência exata e consensual entre os perfis geneticamente determinado por microarranjos de DNA e imunoistoquímico existe uma boa aproximação $^{(17 ; 18 ; 63)}$. Podemos constatar que, na prática, a abordagem dos carcinomas mamários é feita discriminando-os nos três perfis imunoistoquímicos: 1) receptor positivo, 2) HER2 positivo e receptores 
negativos e 3) triplos-negativos. Estes perfis refletem, de certa maneira, o subtipo genético intrínseco. Biologicamente os carcinomas mamários pouco diferenciados são distintos e podem corresponder tanto a neoplasias do grupo luminal quanto HER2 e triplo-negativo. Neste cenário iniciamos nosso estudo, a princípio esperando um significante predomínio de tumores basal-símile

Nossos resultados nos mostraram que, mesmo analisando tumores com pouca ou nenhuma formação tubular, o subtipo imunoistoquímico luminal, definido pela expressão dos receptores hormonais, foi o mais freqüente, responsável por $54,5 \%$ da nossa casuística. Nestes casos, a coexpressão do HER2 não teve impacto sobre outros fatores prognósticos e preditivos como o tamanho do tumor, envolvimento de linfonodos axilares, idade da paciente, embolização vascular e atividade proliferativa determinada pela contagem mitótica ou expressão do Ki67. Sugerimos, então, que carcinomas pouco diferenciados com receptores hormonais(+), correspondem ao subgrupo luminal B genético, independente da expressão do HER2. No entanto, este subgrupo mostrou a menor atividade proliferativa quando comparado com os subgrupos imunoistoquímicos triplo-negativo e HER2, confirmando que são, provavelmente, menos agressivos. Estes resultados nos indicam que o grau histológico em carcinomas do tipo luminal discrimina o subgrupo de maior agressividade, provavelmente o subtipo B, e, provavelmente, os tumores que sejam resistentes à terapia hormonal e/ou tenham maior benefício com quimioterapia. Podemos dizer que, atualmente, o grande desafio diante dos carcinomas luminais é justamente discriminar 
aqueles que tenham benefício com a quimioterapia, objeto, inclusive, dos testes genéticos como o teste de 21-genes.

A presença de citoqueratinas basais foi observada em 53 (39.5\%) tumores, a maioria (54.7\%) no subgrupo triplo-negativo, correspondendo provavelmente aos tumores verdadeiramente basal-símiles. Os tumores positivos para as citoqueratinas basais tiveram maior associação com pacientes jovens $(25 \%$ vs. $8.8 \%)$, aumentando a probabilidade da associação com a mutação do gene BRCA-1. Esta associação tem sido bastante discutida na literatura. Foulkes e colaboradores, em 2003 relataram que 40 de 72 tumores que carregavam a mutação do gene BRCA-1 expressavam CK 5/6; mutação também associada aos carcinomas de padrão basal genético ${ }^{(13 ; 64 ; 65)}$.

A imunoexpressão de citoqueratinas basais tem sido relatada a prognóstico pior (16;66-68). Van de Rijin e colaboradores, em 2002 demonstraram que a expressão imunoistoquímica de citoqueratinas basais 17 e 5/6, além de ser associada a curso clínico desfavorável, apresentou valor prognóstico independente no grupo de pacientes com axila negativa. Malzahn e colaboradores, em 1998 demonstraram, ainda, a associação entre carcinomas de mama positivos para citoqueratinas basais (14 e 17) e sobrevida/tempo livre de doença curtos no subgrupo com alto grau histológico, receptor de estrogênio e vimentina negativos. Estes resultados adicionados aos achados de microarranjos de DNA suportam a idéia que a expressão de citoqueratinas basais podem identificar um grupo distinto de carcinoma de mama, relacionado às células basais; grupo este diferente do luminal que engloba a maior parte dos carcinomas. 
Rakha e colaboradores, em 2007 sugeriram que o subtipo basalsímile poderia ser definido baseado na positividade para as citoqueratinas basais, não importando a expressão de outros marcadores como o estrógeno, progesterona, receptores de andrógeno, EGFR, HER2, BRCA1, p-caderina e marcadores mioepiteliais (actina de músculo liso e p63). Na opinião destes autores, mesmo que outros marcadores sejam associados ao painel imunoistoquímico, juntamente com as citoqueratinas basais, eles não ajudariam no reconhecimento de casos com diferente evolução, reduzindo assim consideravelmente a proporção de casos com pior prognóstico relacionados aos carcinomas de mama basal-símile, quando comparados com o painel constituído exclusivamente pelas citoqueratinas basais.

Devemos ressaltar que falar em citoqueratinas basais, não é falar em carcinomas geneticamente de padrão basal, apesar de que provavelmente a maior parte destes tumores expressarem esta proteína. Nós encontramos positividade para as citoqueratinas basais nos três grupos de carcinomas, considerando a expressão dos receptores hormonais e do HER2, contudo esta positividade foi mais freqüente no grupo triplo-negativo (74.4\% vs. $25.3 \%)$.

Quando nós comparamos os tumores com e sem a expressão das citoqueratinas basais, também os identificamos como mais agressivos. Observamos que tumores maiores que $2,0 \mathrm{~cm}$, em pacientes jovens, com alta atividade proliferativa, com maiores áreas de necrose, preferencialmente triplo-negativos e com pouca ou nenhuma expressão de CK8/18 foram predominantes no grupo com expressão das citoqueratinas basais. Nas 
análises multivariadas,o único fator preditivo independente da expressão de citoqueratinas basais foi a característica de ser triplo-negativo $(p<0,0001)$, sugerindo que a expressão de uma das citoqueratinas basais é suficiente para definir o fenótipo basal-símile.

Os tumores triplo-negativos de acordo com a imunoistoquímica têm sido o foco de muitas pesquisas, desde que foram associados ao fenótipo basal ${ }^{(9 ; 10 ; 13)}$. O fator preditivo independente ligado aos tumores triplonegativos foi a expressão de citoqueratinas basais $(p<0.0001)$.

No entanto, assim como o aplicado para as citoqueratinas basais, o fenótipo triplo-negativo não deve ser considerado sinônimo de carcinoma basal-símile, pois a amplificação do HER2 pode estar presente em uma parte destes tumores, assim como este fenótipo pode estar presente em outros padrões genéticos de carcinoma de mama ${ }^{(15)}$. Os carcinomas basais genéticos com a amplificação do HER2 têm outros marcadores que indicam diferenciação basal, como as citoqueratinas basais e os marcadores mioepiteliais ${ }^{(47 ; 67)}$.

A heterogeneidade de marcadores co-expressos com citoqueratinas basais explica a diversidade nas apresentações de definições dos carcinomas basal-símiles. Fulford e col (2007) propuseram a existência de dois subgrupos de carcinomas basais genéticos: um exibindo recidiva precoce, curso clínico agressivo e com alto risco de desenvolver metástases cerebrais, e um segundo subgrupo que apesar dos indicadores de prognóstico ruim, tem menor probabilidade de recidiva ${ }^{(69)}$. 
Outros marcadores deste grupo de carcinomas têm sido descritos como vimentina, EGFR, p-caderina e c-kit, nenhum deles com alta especificidade ${ }^{(17 ; 18 ; 70)}$. Das características morfológicas freqüentemente encontradas nestes tumores estão o alto grau histológico, contagem mitótica elevada, necrose tumoral geográfica, bordas expansivas e resposta estromal linfocítica ${ }^{(17 ; 18 ; 70)}$.

Dos carcinomas de mama pouco diferenciados, $21,6 \%$ foram triplonegativo e expressaram pelo menos uma das citoqueratinas basais, determinando o subgrupo basal-símile imunoistoquímico. Considerando que os carcinomas basal-símile genético representam $15 \%$ dos carcinomas de mama ${ }^{(10)}$, nossa maior porcentagem provavelmente se deve ao alto grau histológico de nossos tumores, visto que outros autores já relataram porcentagens semelhantes $(20 \%)$ em estudos onde todos os tumores eram carcinomas ductais invasivos ${ }^{(69)}$.

Em nosso estudo, os carcinomas que tiveram o perfil imunoistoquímico basal-símile não diferiram do perfil HER2 com relação ao número de pacientes com idade $\leq 40$ anos, tamanho do tumor, presença de necrose, presença de embolização vascular linfática extensa, presença de acometimento linfonodal axilar e expressão imunoistoquímica de p63, VEGF-A, EGFR, c-Kit e CK8/18. De fato, as únicas diferenças entre estes dois grupos foram: a presença de componente "in situ", mais freqüente no segundo grupo $(68.2 \%$ vs $30.8 \%, p=0.0071)$ e a expressão de citoqueratinas basais, mais comum no primeiro grupo $(74.4 \%$ vs $27.3 \%, p=0.0005)$. No entanto estas características foram diferentes quando comparamos os subgrupos 
triplo-negativo e receptores hormonais $(+)$, estes últimos, como já citado, apresentaram características morfológicas e imunoistoquímicas de doença menos agressiva que os primeiros.

Nosso trabalho mostrou claramente que a presença dos receptores hormonais definem um grupo de carcinomas de mama morfologicamente com evolução mais favorável. Resumidamente os carcinomas de mama pouco diferenciados podem corresponder ao tipo luminal B, HER2, mama normal ou basal-símile. Fatores de prognóstico clássicos relacionados com o potencial agressivo como pacientes jovens, tamanho do tumor, atividade proliferativa e necrose foram similares entre os subtipos HER2 e triplo-negativo. No entanto, a imunoexpressão das citoqueratinas basais diferenciam os dois grupos e podem sugerir o provável carcinoma basal-símile e o padrão de doença associado à este fenótipo. Concluímos que entre os carcinomas de mama pouco diferenciados de mama, o painel imunoistoquímico clássico (receptores hormonais e HER2) associado à expressão de pelo menos uma das citoqueratinas basais permitem a identificação dos distintos subtipos, equivalentes aos vistos na classificação genética. 
6. Conclusões 
1. Dentre os carcinomas mamários invasivos pouco diferenciados, o subtipo luminal foi o mais freqüente (73 casos ou $54,5 \%$ ), seguido pelo subtipo triplo-negativo (39 casos ou $29,1 \%$ ) e, mais raramente, do subtipo HER2 (22 casos ou 16,4\%).

2. Os subtipos básicos diferem entre si segundo tamanho do tumor, freqüência de necrose e embolização vascular peritumoral, e atividade proliferativa determinada pela contagem mitótica e expressão de Ki-67, com perfil mais favorável no subtipo luminal e mais agressivo nos triplos negativos e HER2.

3. A expressão de citoqueratinas basais é mais freqüente entre os carcinomas triplo-negativos, enquanto que as citoqueratinas luminais predominam no subtipo luminal

4. Neoplasias com expressão de citoqueratinas basais acometem mais frequentemente mulheres jovens, são maiores, têm mais necrose, maior atividade proliferativa segundo expressão do Ki-67 e têm no fenótipo triplonegativo seu maior valor preditivo, sugerindo que a expressão de uma das citoqueratinas basais é suficiente para definir o fenótipo basal-símile. 
5. Os carcinomas de mama pouco diferenciados $\mathrm{RH}(+)$ com ou sem expressão de HER2, não mostraram diferenças entre si quanto às características estudadas, mas apresentam características morfológicas e imunoistoquímicas mais favoráveis em relação aos demais grupos, indicando que os tumores $\mathrm{RH}(+)$ podem pertencer ao subgrupo luminal $\mathrm{B}$ genético. 
7. Anexos 
Anexo A - Cadastro dos dados anátomo-patológicos e resultados do estudo imunoistoquímico

\begin{tabular}{|c|c|c|c|c|c|c|c|c|c|c|c|c|c|c|}
\hline $\begin{array}{c}\mathrm{N}^{\circ} \\
\text { Caso }\end{array}$ & Idade & Axila & $\begin{array}{c}\mathrm{L} \\
\text { Dissecados }\end{array}$ & $\begin{array}{c}\mathrm{L} \\
\text { Positivos } \\
\end{array}$ & $\begin{array}{c}\mathrm{L} \\
\text { Tamanho }\end{array}$ & $\mathrm{pN}$ & $\mathrm{T}$ & $\begin{array}{c}\text { Tipo } \\
\text { Histologico } \\
\end{array}$ & $\begin{array}{c}\text { Grau } \\
\text { Histologico }\end{array}$ & $\begin{array}{c}\text { Grau } \\
\text { Tubular }\end{array}$ & $\begin{array}{c}\text { Grau } \\
\text { Pleomorfismo }\end{array}$ & Mitoses & CDIS & EVL \\
\hline 1 & 0 & Sim & 17 & 3 & 2,2 & $\mathrm{pN} 1 \mathrm{a}$ & 5 & CDI & 3 & 3 & 3 & 2 & Não & Não \\
\hline 2 & 60 & Não & 0 & 0 & 0 & $\mathrm{pNx}$ & 3,5 & CDI & 3 & 3 & 3 & 2 & Não & Sim \\
\hline 3 & 21 & Sim & 19 & 16 & 1 & pN3a & 3,5 & CDI & 3 & 3 & 3 & 2 & Sim & Sim \\
\hline 4 & 28 & Sim & 21 & 0 & 0 & pNo & 2,8 & CDI & 3 & 3 & 3 & 2 & Sim & Não \\
\hline 5 & 30 & Sim & 19 & 0 & 0 & pNo & 3 & CDI & 3 & 3 & 3 & 3 & Não & Não \\
\hline 6 & 30 & Sim & 4 & 3 & 5,1 & $\mathrm{pN} 1 \mathrm{a}$ & 9 & CDI & 3 & 3 & 3 & 3 & Não & Sim \\
\hline 7 & 33 & Sim & 21 & 0 & 0 & pNo & 2,4 & CDI & 3 & 3 & 3 & 2 & Não & Não \\
\hline 8 & 33 & Sim & 18 & 2 & 2,3 & $\mathrm{pN} 1 \mathrm{a}$ & 4 & CDI & 3 & 3 & 3 & 2 & Sim & Sim \\
\hline 9 & 33 & Sim & 20 & 0 & 0 & pNo & 16 & CDI & 3 & 3 & 3 & 3 & Não & Não \\
\hline 10 & 34 & Sim & 24 & 6 & 2,8 & $\mathrm{pN} 2 \mathrm{a}$ & 3,5 & CDI & 3 & 3 & 3 & 2 & Não & Sim \\
\hline 11 & 35 & Sim & 9 & 9 & 0,7 & $\mathrm{pN} 2 \mathrm{a}$ & 3 & CDI & 2 & 3 & 3 & 1 & Sim & Não \\
\hline 12 & 35 & Sim & 12 & 12 & 2,1 & pN3a & 8 & CDI & 3 & 3 & 3 & 2 & Sim & Não \\
\hline 13 & 36 & Sim & 13 & 8 & 2,5 & $\mathrm{pN} 2 \mathrm{a}$ & 4 & CDI & 3 & 3 & 3 & 2 & Sim & Sim \\
\hline 14 & 37 & Sim & 16 & 2 & 1,5 & $\mathrm{pN} 1 \mathrm{a}$ & 4 & CDI & 3 & 3 & 3 & 2 & Sim & Não \\
\hline 15 & 37 & Sim & 19 & 19 & 3 & pN3a & 8 & CDI & 3 & 3 & 3 & 3 & Não & Sim \\
\hline 16 & 37 & Sim & 12 & 11 & 4 & pN3a & 10 & CDI & 2 & 3 & 3 & 1 & Sim & Sim \\
\hline 17 & 38 & Sim & 33 & 4 & 1,5 & $\mathrm{pN} 2 \mathrm{a}$ & 4,5 & CDI & 3 & 3 & 3 & 2 & Sim & Não \\
\hline 18 & 38 & Sim & 2 & 22 & 0 & pN1a & 1 & CDI & 3 & 3 & 3 & 3 & Sim & Não \\
\hline 19 & 39 & Sim & 23 & 0 & 0 & pNo & 0 & CDI & 3 & 3 & 3 & 2 & Sim & Não \\
\hline 20 & 39 & Sim & 8 & 8 & 1,8 & $\mathrm{pN} 2 \mathrm{a}$ & 8 & CDI & 3 & 3 & 3 & 3 & Sim & Sim \\
\hline 21 & 39 & Sim & 26 & 3 & 1,4 & pN1a & 5 & Outro & 2 & 3 & 3 & 1 & Sim & Sim \\
\hline 22 & 40 & Sim & 17 & 4 & 1,2 & $\mathrm{pN} 2 \mathrm{a}$ & 15 & Outro & 3 & 3 & 3 & 3 & Não & Sim \\
\hline 23 & 41 & Sim & 15 & 11 & 3 & pN3a & 6,5 & CDI & 3 & 3 & 3 & 3 & Não & Sim \\
\hline 24 & 41 & Sim & 17 & 10 & 2 & pN3a & 3 & CDI & 2 & 3 & 3 & 1 & Sim & Sim \\
\hline 25 & 41 & Sim & 20 & 1 & 0 & pN1a & 3 & CDI & 3 & 3 & 3 & 2 & Sim & Não \\
\hline 26 & 42 & Não & 0 & 0 & 0 & pNx & 0 & CDI & 3 & 3 & 3 & 2 & Não & Não \\
\hline 27 & 42 & Sim & 20 & 0 & 0 & pN0 & 1,5 & CDI & 3 & 3 & 3 & 3 & Sim & Não \\
\hline 28 & 43 & Sim & 16 & 0 & 0 & pNo & 2 & CDI & 3 & 3 & 3 & 3 & Não & Não \\
\hline
\end{tabular}


Anexo A - Cadastro dos dados anátomo-patológicos e resultados do estudo imunoistoquímico

\begin{tabular}{|c|c|c|c|c|c|c|c|c|c|c|c|c|c|c|}
\hline $\begin{array}{l}\mathrm{N}^{\circ} \\
\text { Caso }\end{array}$ & Idade & Axila & $\begin{array}{c}\mathrm{L} \\
\text { Dissecados }\end{array}$ & $\begin{array}{c}\mathrm{L} \\
\text { Positivos } \\
\end{array}$ & $\begin{array}{c}\mathrm{L} \\
\text { Tamanho }\end{array}$ & $\mathrm{pN}$ & $\mathrm{T}$ & $\begin{array}{c}\text { Tipo } \\
\text { Histologico } \\
\end{array}$ & $\begin{array}{c}\text { Grau } \\
\text { Histologico }\end{array}$ & $\begin{array}{c}\text { Grau } \\
\text { Tubular }\end{array}$ & $\begin{array}{c}\text { Grau } \\
\text { Pleomorfismo }\end{array}$ & Mitoses & CDIS & EVL \\
\hline 29 & 43 & Sim & 26 & 4 & 1,5 & $\mathrm{pN} 2 \mathrm{a}$ & 4 & CDI & 3 & 3 & 2 & 2 & Sim & Sim \\
\hline 30 & 43 & Sim & 11 & 2 & 2 & $\mathrm{pN} 1 \mathrm{a}$ & 0,6 & CDI & 3 & 3 & 3 & 2 & Não & Não \\
\hline 31 & 45 & Sim & 21 & 0 & 0 & pNo & 2 & CDI & 3 & 3 & 3 & 2 & Sim & Sim \\
\hline 32 & 45 & Sim & 22 & 12 & 2 & $\mathrm{pN} 3 a$ & 4 & CDI & 2 & 3 & 3 & 1 & Não & Sim \\
\hline 33 & 45 & Sim & 23 & 8 & 2 & $\mathrm{pN} 2 \mathrm{a}$ & 3,5 & CDI & 3 & 3 & 3 & 3 & Não & Sim \\
\hline 34 & 45 & Sim & 13 & 9 & 1,8 & $\mathrm{pN} 2 \mathrm{a}$ & 0,5 & CDI & 2 & 3 & 3 & 1 & Sim & Não \\
\hline 35 & 45 & Não & 0 & 0 & 0 & $\mathrm{pNx}$ & 0 & CDI & 3 & 3 & 3 & 2 & Sim & Não \\
\hline 36 & 45 & Sim & 23 & 8 & 2 & $\mathrm{pN} 2 \mathrm{a}$ & 3,5 & CDI & 3 & 3 & 3 & 3 & Sim & Sim \\
\hline 37 & 45 & Sim & 24 & 6 & 0 & $\mathrm{pN} 2 \mathrm{a}$ & 10 & CDI & 3 & 3 & 3 & 2 & Sim & Sim \\
\hline 38 & 46 & Sim & 18 & 15 & 3 & pN3a & 0 & CDI & 3 & 3 & 3 & 2 & Não & Sim \\
\hline 39 & 46 & Sim & 19 & 4 & 1,5 & $\mathrm{pN} 2 \mathrm{a}$ & 0,5 & CDI & 3 & 3 & 3 & 3 & Sim & Não \\
\hline 40 & 46 & Sim & 17 & 16 & 3 & pN3a & 7,5 & CDI & 3 & 3 & 3 & 2 & Sim & Sim \\
\hline 41 & 46 & Sim & 22 & 3 & 0 & $\mathrm{pN} 1 \mathrm{a}$ & 3,8 & CDI & 3 & 3 & 3 & 2 & Não & Sim \\
\hline 42 & 46 & Sim & 18 & 14 & 2 & pN3a & 3 & CDI & 2 & 3 & 3 & 1 & Sim & Sim \\
\hline 43 & 47 & Sim & 21 & 1 & 2,2 & pN1a & 4 & CDI & 3 & 3 & 3 & 2 & Não & Sim \\
\hline 44 & 47 & Não & 0 & 0 & 0 & $\mathrm{pNx}$ & 0 & CDI & 3 & 3 & 3 & 2 & Sim & Não \\
\hline 45 & 48 & Sim & 6 & 0 & 0 & pNo & 2,4 & CDI & 3 & 3 & 3 & 2 & Sim & Não \\
\hline 46 & 48 & Não & 0 & 0 & 0 & $\mathrm{pNx}$ & 0 & CDI & 3 & 3 & 3 & 2 & Sim & Não \\
\hline 47 & 48 & Sim & 18 & 2 & 1,1 & $\mathrm{pN} 1 \mathrm{a}$ & 4,5 & CDI & 3 & 2 & 3 & 3 & Sim & Não \\
\hline 48 & 49 & Sim & 17 & 11 & 1,5 & pN3a & 2 & CDI & 3 & 3 & 3 & 3 & Sim & Sim \\
\hline 49 & 49 & Sim & 15 & 0 & 0 & pN0 & 1 & CDI & 2 & 3 & 2 & 2 & Sim & Não \\
\hline 50 & 49 & Sim & 21 & 2 & 6 & pN1a & 14 & CDI & 3 & 3 & 3 & 3 & Não & Não \\
\hline 51 & 49 & Sim & 9 & 0 & 0 & pN0 & 3,5 & CDI & 3 & 3 & 3 & 2 & Não & Não \\
\hline 52 & 49 & Sim & 9 & 8 & 2 & $\mathrm{pN} 2 \mathrm{a}$ & 3 & CDI & 3 & 3 & 3 & 2 & Não & Sim \\
\hline 53 & 50 & Não & 0 & 0 & 0 & pNx & 0 & CDI & 3 & 3 & 3 & 2 & Não & Não \\
\hline 54 & 50 & Sim & 23 & 2 & 1,5 & pN1a & 13 & 3 & 3 & 3 & 3 & 3 & Sim & Não \\
\hline 55 & 51 & Não & 0 & 0 & 0 & pNo & 1,8 & CDI & 3 & 3 & 3 & 1 & Não & Não \\
\hline 56 & 51 & Sim & 26 & 8 & 3 & $\mathrm{pN} 3 a$ & 6 & CDI & 3 & 3 & 3 & 3 & Não & Não \\
\hline
\end{tabular}


Anexo A - Cadastro dos dados anátomo-patológicos e resultados do estudo imunoistoquímico

\begin{tabular}{|c|c|c|c|c|c|c|c|c|c|c|c|c|c|c|}
\hline $\begin{array}{c}\mathrm{N}^{\circ} \\
\text { Caso } \\
\end{array}$ & Idade & Axila & $\begin{array}{c}\mathrm{L} \\
\text { Dissecados }\end{array}$ & $\begin{array}{c}\mathrm{L} \\
\text { Positivos }\end{array}$ & $\begin{array}{c}\mathrm{L} \\
\text { Tamanho }\end{array}$ & $\mathrm{pN}$ & $\mathrm{T}$ & $\begin{array}{c}\text { Tipo } \\
\text { Histologico } \\
\end{array}$ & $\begin{array}{c}\text { Grau } \\
\text { Histologico }\end{array}$ & $\begin{array}{c}\text { Grau } \\
\text { Tubular }\end{array}$ & $\begin{array}{c}\text { Grau } \\
\text { Pleomorfismo }\end{array}$ & Mitoses & CDIS & EVL \\
\hline 57 & 51 & Sim & 31 & 4 & 3 & $\mathrm{pN} 2 \mathrm{a}$ & 5 & CDI & 3 & 3 & 3 & 2 & Não & Não \\
\hline 58 & 51 & Sim & 20 & 3 & 1,2 & $\mathrm{pN} 1 \mathrm{a}$ & 9 & CDI & 3 & 3 & 3 & 3 & Não & Não \\
\hline 59 & 51 & Sim & 24 & 1 & 1,3 & $\mathrm{pN} 2 \mathrm{~b}$ & 8 & CDI & 3 & 3 & 3 & 3 & Não & Sim \\
\hline 60 & 51 & Sim & 9 & 0 & 0 & pNo & 2,2 & CDI & 3 & 3 & 3 & 3 & Não & Não \\
\hline 61 & 51 & Sim & 22 & 3 & 2 & $\mathrm{pN} 1 \mathrm{a}$ & 7,5 & CDI & 3 & 3 & 3 & 2 & Não & Não \\
\hline 62 & 52 & Não & 0 & 0 & 0 & $\mathrm{pNx}$ & 0 & CDI & 3 & 3 & 3 & 3 & Não & Não \\
\hline 63 & 52 & Sim & 22 & 10 & 1,6 & $\mathrm{pN} 3 \mathrm{a}$ & 2 & CDI & 2 & 3 & 3 & 1 & Não & Sim \\
\hline 64 & 52 & Sim & 12 & 6 & 2 & $\mathrm{pN} 2 \mathrm{a}$ & 4 & Outro & 3 & 3 & 3 & 2 & Não & Sim \\
\hline 65 & 52 & Sim & 21 & 2 & 1,3 & pN1a & 2,5 & CDI & 3 & 3 & 3 & 2 & Sim & Não \\
\hline 66 & 52 & Sim & 5 & 2 & 3 & $\mathrm{pN} 1 \mathrm{a}$ & 10 & CDI & 3 & 3 & 3 & 3 & Não & Não \\
\hline 67 & 53 & Não & 0 & 0 & 0 & $\mathrm{pNx}$ & 0 & CDI & 2 & 3 & 3 & 1 & Não & Não \\
\hline 68 & 53 & Sim & 29 & 0 & 0 & pNO & 9 & CDI & 3 & 3 & 3 & 3 & Não & Sim \\
\hline 69 & 54 & Não & 0 & 0 & 0 & $\mathrm{pN} 1 \mathrm{a}$ & 3 & CDI & 3 & 3 & 3 & 3 & Sim & Não \\
\hline 70 & 54 & Sim & 16 & 0 & 0 & pNO & 1,5 & CDI & 2 & 3 & 3 & 1 & Sim & Não \\
\hline 71 & 54 & Não & 0 & 0 & 0 & $\mathrm{pNx}$ & 0 & CDI & 3 & 3 & 3 & 3 & Não & Não \\
\hline 72 & 54 & Sim & 30 & 8 & 2 & $\mathrm{pN} 2 \mathrm{a}$ & 7 & CDI & 3 & 3 & 3 & 3 & Não & Não \\
\hline 73 & 54 & Sim & 14 & 0 & 0 & pNo & 2 & CDI & 3 & 3 & 3 & 3 & Sim & Sim \\
\hline 74 & 54 & Sim & 45 & 29 & 4,2 & $\mathrm{pN} 3 \mathrm{a}$ & 6 & CDI & 3 & 3 & 3 & 2 & Não & Sim \\
\hline 75 & 54 & Sim & 17 & 2 & 0 & $\mathrm{pN} 1 \mathrm{a}$ & 2,5 & CDI & 3 & 3 & 3 & 2 & Não & Sim \\
\hline 76 & 54 & Sim & 20 & 1 & 1,8 & pN1a & 1,2 & CDI & 3 & 3 & 3 & 3 & Sim & Não \\
\hline 77 & 55 & Sim & 17 & 17 & 2,7 & $\mathrm{pN} 3 \mathrm{a}$ & 6,5 & CDI & 3 & 3 & 3 & 3 & Não & Sim \\
\hline 78 & 55 & Sim & 17 & 6 & 1 & $\mathrm{pN} 2 \mathrm{a}$ & 10 & Outro & 2 & 3 & 3 & 1 & Sim & Não \\
\hline 79 & 56 & Sim & 19 & 4 & 2 & $\mathrm{pN} 2 \mathrm{a}$ & 4 & CDI & 2 & 3 & 3 & 1 & Sim & Sim \\
\hline 80 & 56 & Sim & 18 & 0 & 0 & pNo & 6 & CDI & 3 & 3 & 3 & 3 & Não & Não \\
\hline 81 & 56 & Sim & 30 & 1 & 1,2 & & 2 & CDI & 3 & 3 & 3 & 3 & Não & Não \\
\hline 82 & 56 & Sim & 30 & 1 & 3,5 & $\mathrm{pN} 1 \mathrm{a}$ & 5 & CDI & 3 & 3 & 3 & 3 & Não & Sim \\
\hline 83 & 56 & Não & 0 & 0 & 0 & pN0 & 1,5 & Outro & 3 & 3 & 3 & 2 & Não & Não \\
\hline 84 & 57 & Sim & 18 & 18 & 3 & $\mathrm{pN} 3 \mathrm{a}$ & 4 & $\mathrm{CDI}$ & 3 & 3 & 3 & 1 & Sim & Não \\
\hline
\end{tabular}


Anexo A - Cadastro dos dados anátomo-patológicos e resultados do estudo imunoistoquímico

\begin{tabular}{|c|c|c|c|c|c|c|c|c|c|c|c|c|c|c|}
\hline $\begin{array}{c}\mathrm{N}^{\circ} \\
\text { Caso } \\
\end{array}$ & Idade & Axila & $\begin{array}{c}\mathrm{L} \\
\text { Dissecados }\end{array}$ & $\begin{array}{c}\mathrm{L} \\
\text { Positivos } \\
\end{array}$ & $\begin{array}{c}\mathrm{L} \\
\text { Tamanho }\end{array}$ & $\mathrm{pN}$ & $\mathrm{T}$ & $\begin{array}{c}\text { Tipo } \\
\text { Histologico } \\
\end{array}$ & $\begin{array}{c}\text { Grau } \\
\text { Histologico }\end{array}$ & $\begin{array}{c}\text { Grau } \\
\text { Tubular }\end{array}$ & $\begin{array}{c}\text { Grau } \\
\text { Pleomorfismo }\end{array}$ & Mitoses & CDIS & EVL \\
\hline 85 & 57 & Não & 0 & 0 & 0 & $\mathrm{pNx}$ & 0 & CDI & 3 & 3 & 3 & 2 & Sim & Não \\
\hline 86 & 57 & Sim & 15 & 0 & 0 & pNO & 11 & Outro & 3 & 3 & 3 & 2 & Não & Não \\
\hline 87 & 57 & Sim & 30 & 29 & 10 & pN3a & 10 & CDI & 3 & 3 & 3 & 2 & Não & Não \\
\hline 88 & 58 & Sim & 14 & 14 & 1,6 & pN3a & 2 & Outro & 3 & 3 & 3 & 2 & Sim & Sim \\
\hline 89 & 59 & Sim & 37 & 26 & 1,7 & pN3a & 1,8 & CDI & 3 & 3 & 3 & 2 & Sim & Sim \\
\hline 90 & 60 & Não & 0 & 0 & 0 & $\mathrm{pNx}$ & 0 & CDI & 3 & 3 & 3 & 2 & Não & Não \\
\hline 91 & 60 & Sim & 14 & 9 & 1,2 & $\mathrm{pN} 2 \mathrm{a}$ & 3 & CDI & 3 & 3 & 3 & 2 & Sim & Sim \\
\hline 92 & 60 & Sim & 25 & 0 & 0 & pNO & 3,5 & CDI & 3 & 3 & 3 & 3 & Não & Não \\
\hline 93 & 61 & Não & 0 & 0 & 0 & $\mathrm{pNx}$ & 0 & CDI & 2 & 3 & 3 & 1 & Não & Não \\
\hline 94 & 61 & Sim & 14 & 0 & 0 & pN1a & 1 & CDI & 3 & 3 & 3 & 1 & Sim & Não \\
\hline 95 & 63 & Sim & 15 & 0 & 0 & $\begin{array}{l}\text { pN1a } \\
\text { (LS) }\end{array}$ & 2,5 & CDI & 3 & 3 & 3 & 2 & Não & Não \\
\hline 96 & 63 & Sim & 33 & 30 & 3,7 & pN3a & 11 & CDI & 3 & 3 & 3 & 2 & Sim & Não \\
\hline 97 & 64 & Não & 0 & 0 & 0 & $\mathrm{pNx}$ & 0 & CDI & 3 & 3 & 3 & 3 & Não & Não \\
\hline 98 & 64 & Não & & 0 & 0 & $\mathrm{pNx}$ & 0 & CDI & 2 & 3 & 3 & 1 & Não & Não \\
\hline 99 & 64 & Não & 0 & 0 & 0 & $\begin{array}{l}\text { pN1a } \\
\text { (LS) }\end{array}$ & 2,8 & Outro & 2 & 3 & 2 & 1 & Sim & Sim \\
\hline 100 & 65 & Sim & 14 & 0 & 0 & pNO & 4,5 & CDI & 3 & 3 & 3 & 3 & Não & Não \\
\hline 101 & 66 & Sim & 27 & 3 & 3,5 & pN1a & 5,6 & CDI & 3 & 3 & 3 & 3 & Não & Não \\
\hline 102 & 68 & Sim & 10 & 0 & 0 & pNO & 2 & CDI & 3 & 3 & 3 & 3 & Sim & Não \\
\hline 103 & 68 & Sim & 22 & 16 & 3,5 & pN3a & 14 & CDI & 3 & 3 & 3 & 2 & Não & Sim \\
\hline 104 & 69 & Não & 0 & 0 & 0 & $\mathrm{pNx}$ & 0 & CDI & 2 & 3 & 3 & 1 & Não & Não \\
\hline 105 & 69 & Sim & 3 & 0 & 0 & pNO & 2,5 & CDI & 3 & 3 & 3 & 2 & Não & Sim \\
\hline 106 & 69 & Não & 0 & 0 & 0 & $\mathrm{pNx}$ & 0 & CDI & 3 & 3 & 3 & 2 & Sim & Não \\
\hline 107 & 69 & Sim & 31 & 0 & 0 & pNO & 1,5 & CDI & 2 & 3 & 3 & 1 & Não & Não \\
\hline 108 & 69 & Sim & 15 & 1 & 1 & pN1a & 2 & CDI & 3 & 3 & 3 & 3 & Sim & Não \\
\hline 109 & 69 & Sim & 15 & 3 & 0 & pN1a & 2,3 & CDI & 3 & 3 & 3 & 2 & Sim & Sim \\
\hline 110 & 70 & Sim & 15 & 0 & 0 & pNO & 2 & CDI & 3 & 3 & 3 & 2 & Sim & Não \\
\hline 111 & 70 & Sim & 17 & 0 & 0 & pNO & 1,3 & CDI & 3 & 3 & 3 & 2 & Sim & Não \\
\hline
\end{tabular}


Anexo A - Cadastro dos dados anátomo-patológicos e resultados do estudo imunoistoquímico

\begin{tabular}{|c|c|c|c|c|c|c|c|c|c|c|c|c|c|c|}
\hline $\begin{array}{c}\mathrm{N}^{\circ} \\
\text { Caso }\end{array}$ & Idade & Axila & $\begin{array}{c}\mathrm{L} \\
\text { Dissecados }\end{array}$ & $\begin{array}{c}\mathrm{L} \\
\text { Positivos } \\
\end{array}$ & $\begin{array}{c}\mathrm{L} \\
\text { Tamanho } \\
\end{array}$ & $\mathrm{pN}$ & $\mathrm{T}$ & $\begin{array}{c}\text { Tipo } \\
\text { Histologico } \\
\end{array}$ & $\begin{array}{c}\text { Grau } \\
\text { Histologico } \\
\end{array}$ & $\begin{array}{c}\text { Grau } \\
\text { Tubular }\end{array}$ & $\begin{array}{c}\text { Grau } \\
\text { Pleomorfismo }\end{array}$ & Mitoses & CDIS & EVL \\
\hline 112 & 70 & Sim & 10 & 6 & 0 & $\mathrm{pN} 2 \mathrm{a}$ & 15 & CDI & 2 & 3 & 3 & 2 & Não & Sim \\
\hline 113 & 71 & Sim & 13 & 0 & 0 & pNo & 7 & CDI & 3 & 3 & 3 & 2 & Sim & Não \\
\hline 114 & 71 & Sim & 27 & 22 & 3 & pN3a & 5 & CDI & 3 & 3 & 3 & 3 & Não & Não \\
\hline 115 & 71 & Sim & 25 & 2 & 1,2 & $\mathrm{pN} 1 \mathrm{a}$ & 3,7 & CDI & 3 & 3 & 3 & 3 & Sim & Não \\
\hline 116 & 71 & Sim & 20 & 20 & 3 & $\mathrm{pN} 3 a$ & 6 & CDI & 2 & 3 & 3 & 1 & Sim & Sim \\
\hline 117 & 72 & Sim & 21 & 1 & 2,5 & pN1a & 5,5 & CDI & 2 & 3 & 3 & 1 & Sim & Não \\
\hline 118 & 73 & Sim & 11 & 0 & 0 & pNo & 2 & CDI & 2 & 3 & 2 & 1 & Sim & Não \\
\hline 119 & 74 & Sim & 29 & 3 & 2,5 & pN1a & 6 & CDI & 3 & 3 & 3 & 3 & Sim & Não \\
\hline 120 & 74 & Sim & 14 & 0 & 0 & pNO & 1,8 & CDI & 2 & 3 & 3 & 1 & Sim & Não \\
\hline 121 & 76 & Sim & 12 & 1 & 1,8 & $\mathrm{pN} 1 \mathrm{a}$ & 2 & CDI & 3 & 3 & 3 & 2 & Sim & Não \\
\hline 122 & 76 & Não & 0 & 0 & 0 & pNo & 1 & CDI & 3 & 3 & 3 & 2 & Sim & Não \\
\hline 123 & 77 & Sim & 12 & 2 & 2 & pN1a & 2 & CDI & 3 & 3 & 3 & 2 & Não & Não \\
\hline 124 & 78 & Sim & 24 & 6 & 3 & $\mathrm{pN} 2 \mathrm{a}$ & 4 & CDI & 2 & 3 & 3 & 1 & Sim & Não \\
\hline 125 & 78 & Sim & 15 & 13 & 3 & pN3a & 2,1 & CDI & 3 & 3 & 3 & 2 & Sim & Não \\
\hline 126 & 79 & Sim & 16 & 5 & 2 & $\mathrm{pN} 2 \mathrm{a}$ & 1,3 & CDI & 3 & 3 & 3 & 2 & Sim & Não \\
\hline 127 & 80 & Sim & 16 & 7 & 3 & $\mathrm{pN} 2 \mathrm{a}$ & 6,5 & CDI & 2 & 3 & 3 & 1 & Não & Não \\
\hline 128 & 82 & Não & 0 & 0 & 0 & pNo & 1,8 & CDI & 3 & 3 & 3 & 2 & Sim & Não \\
\hline 129 & 82 & Sim & 11 & 0 & 0 & pNo & 2,5 & Outro & 3 & 3 & 3 & 2 & Sim & Sim \\
\hline 130 & 83 & Não & 0 & 0 & 0 & $\mathrm{pNx}$ & 0 & CDI & 3 & 3 & 3 & 2 & Não & Não \\
\hline 131 & 85 & Sim & 13 & 0 & 0 & pNo & 3,5 & Outro & 3 & 3 & 3 & 2 & Não & Não \\
\hline 132 & 87 & Sim & 18 & 0 & 0 & pNo & 1,8 & CDI & 3 & 3 & 3 & 2 & Sim & Não \\
\hline 133 & 89 & Sim & 19 & 13 & 4 & pN3a & 9 & CDI & 3 & 3 & 3 & 3 & Sim & Sim \\
\hline 134 & 94 & Sim & 6 & 1 & 2 & pN1a & 9,5 & CDI & 3 & 3 & 3 & 3 & Sim & Não \\
\hline
\end{tabular}


Anexo A - Cadastro dos dados anátomo-patológicos e resultados do estudo imunoistoquímico

\begin{tabular}{|c|c|c|c|c|c|c|c|c|c|c|c|c|c|c|}
\hline $\begin{array}{c}\mathrm{N}^{\circ} \\
\text { Caso }\end{array}$ & Procedimento & Lateralidade & RE & $\mathrm{RP}$ & HER2 & $\mathrm{KI} 67$ & CK_5 & CK 14 & CK 17 & EGFR & CK 8/18 & C-Kit & $P \_63$ & VEGF-A \\
\hline 1 & Quadrantectomia & Esquerdo & Positivo & Negativo & Negativo & Positivo & 1 & 1 & 1 & 1 & 1 & 1 & 1 & 3 \\
\hline 2 & Mastectomia & Esquerdo & Negativo & Negativo & Negativo & Negativo & 3 & 1 & 1 & 1 & 1 & 1 & 1 & 1 \\
\hline 3 & Mastectomia & Direito & Positivo & Positivo & Negativo & Positivo & 2 & 2 & 3 & 1 & 4 & 1 & 1 & 1 \\
\hline 4 & Quadrantectomia & Esquerdo & Positivo & Positivo & Negativo & Negativo & 1 & 1 & 1 & 1 & 1 & 1 & 1 & 3 \\
\hline 5 & Mastectomia & Direito & Negativo & Negativo & Negativo & Positivo & 4 & 2 & 2 & 2 & 4 & 1 & 1 & 1 \\
\hline 6 & Mastectomia & Desconhecido & Negativo & Positivo & Negativo & Positivo & 4 & 2 & 3 & 1 & 1 & 4 & 1 & 2 \\
\hline 7 & Quadrantectomia & Esquerdo & Negativo & Negativo & Negativo & Positivo & 4 & 1 & 2 & 1 & 1 & 2 & 1 & 2 \\
\hline 8 & Mastectomia & Esquerdo & Negativo & Negativo & Negativo & Positivo & 0 & 2 & 2 & 1 & 1 & 1 & 1 & 2 \\
\hline 9 & Mastectomia & Direito & Negativo & Negativo & Negativo & Positivo & 2 & 1 & 1 & 1 & 1 & 1 & 1 & 1 \\
\hline 10 & Mastectomia & Esquerdo & Positivo & Positivo & Negativo & Positivo & 1 & 1 & 1 & 1 & 4 & 1 & 1 & 1 \\
\hline 11 & Mastectomia & Direito & Positivo & Negativo & Negativo & Negativo & 1 & 1 & 2 & 1 & 4 & 1 & 1 & 2 \\
\hline 12 & Mastectomia & Direito & Positivo & Positivo & Positivo & Positivo & 1 & 1 & 1 & 1 & 4 & 2 & 1 & 3 \\
\hline 13 & Mastectomia & Esquerdo & Positivo & Positivo & Positivo & Positivo & 1 & 2 & 1 & 1 & 4 & 1 & 1 & 3 \\
\hline 14 & Mastectomia & Direito & Negativo & Negativo & Negativo & Positivo & 3 & 2 & 1 & 1 & 1 & 1 & 1 & 2 \\
\hline 15 & Mastectomia & Direito & Negativo & Negativo & Negativo & Positivo & 4 & 2 & 1 & 1 & 4 & 1 & 1 & 1 \\
\hline 16 & Mastectomia & Direito & Negativo & Negativo & Positivo & Positivo & 1 & 1 & 1 & 1 & 4 & 1 & 1 & 1 \\
\hline 17 & Mastectomia & Direito & Positivo & Positivo & Negativo & Positivo & 1 & 1 & 1 & 1 & 4 & 2 & 1 & 1 \\
\hline 18 & Mastectomia & Direito & Positivo & Positivo & Positivo & Positivo & 1 & 0 & 0 & 0 & 0 & 0 & 0 & 0 \\
\hline 19 & Setorectomia & Direito & Positivo & Positivo & Negativo & Positivo & 2 & 1 & 0 & 1 & 0 & 1 & 1 & 3 \\
\hline 20 & Mastectomia & Esquerdo & Negativo & Negativo & Positivo & Positivo & 1 & 1 & 1 & 1 & 4 & 1 & 1 & 4 \\
\hline 21 & Mastectomia & Esquerdo & Negativo & Negativo & Positivo & Negativo & 2 & 2 & 1 & 1 & 4 & 1 & 1 & 1 \\
\hline 22 & Mastectomia & Esquerdo & Positivo & Positivo & Negativo & Negativo & 4 & 1 & 4 & 1 & 1 & 1 & 1 & 3 \\
\hline 23 & Mastectomia & Esquerdo & Negativo & Negativo & Negativo & Positivo & 3 & 2 & 3 & 1 & 1 & 1 & 1 & 3 \\
\hline 24 & Mastectomia & Direito & Negativo & Negativo & Positivo & Negativo & 0 & 1 & 1 & 1 & 4 & 1 & 1 & 1 \\
\hline 25 & Mastectomia & Esquerdo & Negativo & Negativo & Negativo & Positivo & 4 & 2 & 2 & 1 & 4 & 1 & 1 & 1 \\
\hline 26 & BAG & Desconhecido & Positivo & Positivo & Positivo & Negativo & 0 & 0 & 1 & 0 & 0 & 0 & 0 & 0 \\
\hline 27 & Mastectomia & Direito & Positivo & Positivo & Negativo & Positivo & 2 & 1 & 1 & 1 & 4 & 1 & 1 & 2 \\
\hline 28 & Quadrantectomia & Esquerdo & Negativo & Negativo & Negativo & Positivo & 1 & 1 & 1 & 1 & 1 & 1 & 1 & 4 \\
\hline
\end{tabular}


Anexo A - Cadastro dos dados anátomo-patológicos e resultados do estudo imunoistoquímico

\begin{tabular}{|c|c|c|c|c|c|c|c|c|c|c|c|c|c|c|}
\hline $\begin{array}{c}\mathrm{N}^{\circ} \\
\text { Caso }\end{array}$ & Procedimento & Lateralidade & RE & $\mathrm{RP}$ & HER2 & $\mathrm{KI} 67$ & CK_5 & CK 14 & CK 17 & EGFR & CK 8/18 & C-Kit & $P \_63$ & VEGF-A \\
\hline 29 & Mastectomia & Esquerdo & Positivo & Positivo & Negativo & Negativo & 1 & 1 & 1 & 1 & 2 & 1 & 1 & 1 \\
\hline 30 & Mastectomia & Direito & Positivo & Negativo & Negativo & Positivo & 2 & 2 & 2 & 1 & 1 & 1 & 1 & 1 \\
\hline 31 & Mastectomia & Esquerdo & Negativo & Negativo & Positivo & Positivo & 4 & 1 & 3 & 1 & 1 & 1 & 1 & 1 \\
\hline 32 & Mastectomia & Direito & Negativo & Positivo & Negativo & Negativo & 1 & 1 & 1 & 1 & 4 & 3 & 1 & 1 \\
\hline 33 & Mastectomia & Esquerdo & Positivo & Positivo & Negativo & Positivo & 1 & 1 & 1 & 1 & 1 & 1 & 1 & 3 \\
\hline 34 & Quadrantectomia & Direito & Positivo & Positivo & Negativo & Positivo & 1 & 1 & 1 & 1 & 1 & 1 & 1 & 1 \\
\hline 35 & BAG & Desconhecido & Negativo & Negativo & Positivo & Positivo & 0 & 1 & 1 & 1 & 0 & 1 & 0 & 0 \\
\hline 36 & Mastectomia & Esquerdo & Positivo & Positivo & Negativo & Positivo & 1 & 1 & 1 & 1 & 4 & 1 & 1 & 2 \\
\hline 37 & Mastectomia & Esquerdo & Negativo & Negativo & Negativo & Positivo & 4 & 1 & 3 & 2 & 1 & 2 & 1 & 2 \\
\hline 38 & Mastectomia & Desconhecido & Positivo & Negativo & Positivo & Positivo & 1 & 1 & 1 & 1 & 1 & 1 & 1 & 1 \\
\hline 39 & Mastectomia & Esquerdo & Negativo & Positivo & Negativo & Negativo & 1 & 1 & 1 & 1 & 1 & 1 & 1 & 3 \\
\hline 40 & Mastectomia & Direito & Positivo & Positivo & Positivo & Negativo & 2 & 2 & 3 & 1 & 4 & 1 & 1 & 1 \\
\hline 41 & Mastectomia & Esquerdo & Positivo & Positivo & Positivo & Negativo & 1 & 1 & 1 & 1 & 1 & 1 & 1 & 1 \\
\hline 42 & Mastectomia & Esquerdo & Positivo & Positivo & Positivo & Negativo & 4 & 4 & 1 & 1 & 1 & 1 & 1 & 2 \\
\hline 43 & Mastectomia & Direito & Negativo & Negativo & Negativo & Positivo & 3 & 1 & 1 & 1 & 2 & 1 & 1 & 1 \\
\hline 44 & BAG & Esquerdo & Positivo & Positivo & Negativo & Positivo & 1 & 1 & 1 & 1 & 1 & 1 & 1 & 1 \\
\hline 45 & Quadrantectomia & Esquerdo & Negativo & Negativo & Negativo & Positivo & 1 & 1 & 1 & 1 & 1 & 1 & 1 & 4 \\
\hline 46 & BAG & Direito & Positivo & Negativo & Positivo & Positivo & 1 & 2 & 1 & 1 & 4 & 1 & 1 & 0 \\
\hline 47 & Mastectomia & Direito & Negativo & Positivo & Positivo & Positivo & 1 & 1 & 1 & 1 & 1 & 1 & 1 & 3 \\
\hline 48 & Mastectomia & Direito & Negativo & Negativo & Positivo & Positivo & 1 & 1 & 1 & 1 & 1 & 1 & 1 & 1 \\
\hline 49 & Mastectomia & Esquerdo & Positivo & Positivo & Positivo & Positivo & 1 & 1 & 1 & 1 & 4 & 1 & 1 & 1 \\
\hline 50 & Mastectomia & Esquerdo & Negativo & Negativo & Positivo & Positivo & 4 & 1 & 4 & 1 & 1 & 1 & 1 & 1 \\
\hline 51 & Mastectomia & Direito & Negativo & Negativo & Negativo & Positivo & 1 & 2 & 1 & 1 & 1 & 2 & 1 & 2 \\
\hline 52 & Mastectomia & Esquerdo & Positivo & Positivo & Positivo & Positivo & 1 & 2 & 2 & 1 & 1 & 2 & 1 & 4 \\
\hline 53 & BAG & Esquerdo & Negativo & Negativo & Negativo & Positivo & 1 & 1 & 1 & 1 & 1 & 1 & 1 & 1 \\
\hline 54 & Mastectomia & Esquerdo & Negativo & Negativo & Negativo & Positivo & 3 & 1 & 1 & 1 & 1 & 1 & 1 & 1 \\
\hline 55 & Quadrantectomia & Direito & Positivo & Positivo & Negativo & Negativo & 1 & 1 & 1 & 1 & 2 & 1 & 1 & 4 \\
\hline 56 & Mastectomia & Esquerdo & Negativo & Negativo & Positivo & Positivo & 1 & 1 & 4 & 1 & 1 & 1 & 1 & 4 \\
\hline
\end{tabular}


Anexo A - Cadastro dos dados anátomo-patológicos e resultados do estudo imunoistoquímico

\begin{tabular}{|c|c|c|c|c|c|c|c|c|c|c|c|c|c|c|}
\hline $\begin{array}{c}\mathrm{N}^{\circ} \\
\text { Caso } \\
\end{array}$ & Procedimento & Lateralidade & RE & RP & HER2 & $\mathrm{KI} 67$ & CK_5 & CK 14 & CK 17 & EGFR & CK 8/18 & C-Kit & $P \_63$ & VEGF-A \\
\hline 57 & Mastectomia & Direito & Negativo & Negativo & Negativo & Negativo & 1 & 1 & 1 & 1 & 2 & 1 & 1 & 1 \\
\hline 58 & Mastectomia & Esquerdo & Negativo & Negativo & Negativo & Positivo & 2 & 1 & 2 & 1 & 1 & 2 & 1 & 1 \\
\hline 59 & Mastectomia & Esquerdo & Negativo & Negativo & Negativo & Negativo & 2 & 1 & 3 & 1 & 1 & 2 & 1 & 4 \\
\hline 60 & Quadrantectomia & Esquerdo & Positivo & Negativo & Negativo & Positivo & 1 & 1 & 1 & 1 & 4 & 1 & 1 & 4 \\
\hline 61 & Mastectomia & Direito & Negativo & Negativo & Negativo & Positivo & 0 & 1 & 0 & 1 & 1 & 1 & 1 & 1 \\
\hline 62 & BAG & Desconhecido & Negativo & Negativo & Negativo & Positivo & 4 & 1 & 1 & 1 & 1 & 1 & 1 & 4 \\
\hline 63 & Quadrantectomia & Direito & Positivo & Positivo & Positivo & Negativo & 1 & 1 & 1 & 1 & 4 & 1 & 1 & 2 \\
\hline 64 & Mastectomia & Desconhecido & Negativo & Negativo & Negativo & Positivo & 4 & 3 & 1 & 1 & 1 & 1 & 1 & 3 \\
\hline 65 & Mastectomia & Esquerdo & Negativo & Negativo & Positivo & Positivo & 1 & 1 & 1 & 1 & 1 & 1 & 1 & 4 \\
\hline 66 & Mastectomia & Direito & Negativo & Negativo & Negativo & Positivo & 1 & 1 & 1 & 1 & 4 & 1 & 1 & 1 \\
\hline 67 & BAG & Direito & Negativo & Negativo & Negativo & Positivo & 0 & 1 & 0 & 1 & 4 & 1 & 1 & 4 \\
\hline 68 & Mastectomia & Direito & Negativo & Negativo & Negativo & Positivo & 1 & 1 & 1 & 1 & 1 & 1 & 1 & 2 \\
\hline 69 & quadrante & Esquerdo & Positivo & Positivo & Negativo & Positivo & 1 & 1 & 1 & 1 & 4 & 1 & 1 & 3 \\
\hline 70 & Quadrantectomia & Direito & Positivo & Positivo & Positivo & Negativo & 1 & 1 & 2 & 1 & 4 & 1 & 1 & 3 \\
\hline 71 & BAG & Direito & Positivo & Positivo & Negativo & Positivo & 1 & 1 & 1 & 1 & 4 & 1 & 1 & 4 \\
\hline 72 & Mastectomia & Direito & Negativo & Negativo & Positivo & Positivo & 4 & 1 & 3 & 1 & 1 & 1 & 1 & 1 \\
\hline 73 & Mastectomia & Direito & Negativo & Negativo & Positivo & Positivo & 1 & 1 & 1 & 1 & 1 & 1 & 1 & 0 \\
\hline 74 & Mastectomia & Esquerdo & Negativo & Negativo & Positivo & Negativo & 1 & 1 & 1 & 1 & 0 & 1 & 1 & 2 \\
\hline 75 & Mastectomia & Esquerdo & Positivo & Positivo & Positivo & Negativo & 1 & 1 & 1 & 1 & 4 & 1 & 2 & 2 \\
\hline 76 & Mastectomia & Direito & Negativo & Negativo & Positivo & Positivo & 1 & 1 & 1 & 1 & 1 & 1 & 1 & 3 \\
\hline 77 & Mastectomia & Direito & Negativo & Negativo & Positivo & Negativo & 1 & 1 & 1 & 1 & 4 & 1 & 1 & 2 \\
\hline 78 & Mastectomia & Esquerdo & Positivo & Positivo & Positivo & Negativo & 1 & 1 & 1 & 1 & 1 & 1 & 1 & 1 \\
\hline 79 & Mastectomia & Esquerdo & Negativo & Negativo & Positivo & Negativo & 1 & 1 & 1 & 1 & 4 & 2 & 1 & 1 \\
\hline 80 & Mastectomia & Esquerdo & Negativo & Negativo & Positivo & Positivo & 4 & 4 & 3 & 1 & 1 & 1 & 1 & 1 \\
\hline 81 & Mastectomia & Esquerdo & Negativo & Negativo & Negativo & Positivo & 3 & 1 & 4 & 1 & 1 & 1 & 1 & 1 \\
\hline 82 & Mastectomia & Direito & Negativo & Negativo & Positivo & Positivo & 1 & 1 & 0 & 1 & 4 & 1 & 1 & 1 \\
\hline 83 & Adenectomia & Direito & Positivo & Positivo & Negativo & Negativo & 1 & 1 & 1 & 1 & 4 & 1 & 1 & 4 \\
\hline 84 & Mastectomia & Direito & Positivo & Positivo & Negativo & Negativo & 1 & 1 & 1 & 1 & 4 & 1 & 1 & 1 \\
\hline
\end{tabular}


Anexo A - Cadastro dos dados anátomo-patológicos e resultados do estudo imunoistoquímico

\begin{tabular}{|c|c|c|c|c|c|c|c|c|c|c|c|c|c|c|}
\hline $\begin{array}{c}\mathrm{N}^{\circ} \\
\text { Caso } \\
\end{array}$ & Procedimento & Lateralidade & RE & RP & HER2 & $\mathrm{KI} 67$ & CK_5 & CK 14 & CK 17 & EGFR & CK 8/18 & C-Kit & $P \_63$ & VEGF-A \\
\hline 85 & BAG & Esquerdo & Positivo & Positivo & Positivo & Negativo & 1 & 1 & 1 & 1 & 1 & 0 & 0 & 0 \\
\hline 86 & Mastectomia & Direito & Negativo & Negativo & Negativo & Positivo & 4 & 3 & 3 & 1 & 1 & 1 & 2 & 2 \\
\hline 87 & Mastectomia & Desconhecido & Negativo & Negativo & Negativo & Positivo & 1 & 2 & 1 & 1 & 4 & 1 & 1 & 1 \\
\hline 88 & Mastectomia & Esquerdo & Negativo & Negativo & Negativo & Negativo & 1 & 1 & 1 & 4 & 4 & 2 & 1 & 1 \\
\hline 89 & Mastectomia & Esquerdo & Negativo & Negativo & Positivo & Positivo & 1 & 1 & 1 & 1 & 1 & 1 & 1 & 4 \\
\hline 90 & BAG & Desconhecido & Positivo & Negativo & Negativo & Positivo & 1 & 1 & 1 & 1 & 4 & 1 & 1 & 4 \\
\hline 91 & Mastectomia & Direito & Positivo & Positivo & Negativo & Negativo & 1 & 1 & 1 & 1 & 4 & 1 & 1 & 3 \\
\hline 92 & Mastectomia & Esquerdo & Negativo & Negativo & Negativo & Positivo & 3 & 0 & 0 & 0 & 0 & 0 & 0 & 3 \\
\hline 93 & BAG & Desconhecido & Positivo & Negativo & Negativo & Negativo & 1 & 1 & 1 & 1 & 4 & 1 & 3 & 4 \\
\hline 94 & Quadrantectomia & Direito & Positivo & Positivo & Negativo & Positivo & 1 & 1 & 1 & 1 & 4 & 1 & 1 & 4 \\
\hline 95 & Quadrantectomia & Direito & Positivo & Positivo & Negativo & Positivo & 1 & 1 & 1 & 1 & 1 & 1 & 1 & 3 \\
\hline 96 & Mastectomia & Esquerdo & Positivo & Positivo & Positivo & Negativo & 1 & 1 & 1 & 1 & 4 & 1 & 1 & 1 \\
\hline 97 & BAG & Direito & Negativo & Negativo & Negativo & Positivo & 3 & 2 & 3 & 1 & 1 & 1 & 2 & 4 \\
\hline 98 & BAG & Esquerdo & Positivo & Positivo & Negativo & Positivo & 1 & 1 & 1 & 1 & 2 & 1 & 1 & 2 \\
\hline 99 & Quadrantectomia & Esquerdo & Positivo & Positivo & Negativo & Positivo & 1 & 1 & 1 & 1 & 4 & 0 & 0 & 1 \\
\hline 100 & Mastectomia & Esquerdo & Positivo & Positivo & Positivo & Positivo & 1 & 1 & 2 & 1 & 1 & 1 & 1 & 2 \\
\hline 101 & Mastectomia & Esquerdo & Negativo & Negativo & Negativo & Positivo & 0 & 1 & 1 & 1 & 1 & 1 & 1 & 2 \\
\hline 102 & Mastectomia & Esquerdo & Negativo & Negativo & Positivo & Positivo & 1 & 1 & 1 & 1 & 1 & 1 & 1 & 4 \\
\hline 103 & Mastectomia & Esquerdo & Positivo & Positivo & Positivo & Positivo & 0 & 1 & 0 & 0 & 0 & 1 & 1 & 0 \\
\hline 104 & BAG & Desconhecido & Positivo & Positivo & Negativo & Negativo & 1 & 1 & 1 & 1 & 4 & 1 & 1 & 3 \\
\hline 105 & Mastectomia & Direito & Positivo & Positivo & Negativo & Positivo & 0 & 1 & 1 & 1 & 4 & 1 & 1 & 1 \\
\hline 106 & BAG & Direito & Negativo & Negativo & Positivo & Positivo & 1 & 1 & 0 & 1 & 1 & 1 & 1 & 3 \\
\hline 107 & Quadrantectomia & Direito & Positivo & Negativo & Negativo & Negativo & 1 & 2 & 1 & 1 & 1 & 1 & 1 & 1 \\
\hline 108 & Quadrantectomia & Direito & Positivo & Positivo & Negativo & Positivo & 1 & 1 & 2 & 1 & 1 & 1 & 1 & 2 \\
\hline 109 & Quadrantectomia & Esquerdo & Positivo & Positivo & Positivo & Negativo & 1 & 1 & 1 & 1 & 1 & 1 & 1 & 3 \\
\hline 110 & Quadrantectomia & Esquerdo & Positivo & Positivo & Negativo & Positivo & 1 & 1 & 1 & 1 & 4 & 1 & 1 & 3 \\
\hline 111 & Quadrantectomia & Esquerdo & Positivo & Negativo & Negativo & Negativo & 1 & 1 & 1 & 1 & 1 & 1 & 1 & 1 \\
\hline
\end{tabular}


Anexo A - Cadastro dos dados anátomo-patológicos e resultados do estudo imunoistoquímico

\begin{tabular}{|c|c|c|c|c|c|c|c|c|c|c|c|c|c|c|}
\hline $\begin{array}{c}\mathrm{N}^{\circ} \\
\text { Caso } \\
\end{array}$ & Procedimento & Lateralidade & RE & RP & HER2 & KI67 & CK_5 & CK 14 & CK 17 & EGFR & CK 8/18 & C-Kit & $P \_63$ & VEGF-A \\
\hline 112 & Mastectomia & Direito & Positivo & Negativo & Negativo & Negativo & 1 & 1 & 1 & 1 & 4 & 1 & 1 & 1 \\
\hline 113 & Mastectomia & Esquerdo & Negativo & Negativo & Negativo & Negativo & 2 & 1 & 1 & 1 & 4 & 1 & 0 & 1 \\
\hline 114 & Mastectomia & Esquerdo & Positivo & Positivo & Positivo & Positivo & 0 & 1 & 1 & 1 & 1 & 1 & 1 & 1 \\
\hline 115 & Mastectomia & Desconhecido & Positivo & Positivo & Positivo & Positivo & 1 & 1 & 1 & 1 & 4 & 1 & 1 & 1 \\
\hline 116 & Mastectomia & Esquerdo & Negativo & Negativo & Negativo & Positivo & 3 & 4 & 2 & 1 & 1 & 1 & 1 & 1 \\
\hline 117 & Mastectomia & Direito & Negativo & Negativo & Negativo & Positivo & 3 & 2 & 4 & 1 & 1 & 1 & 3 & 1 \\
\hline 118 & Quadrantectomia & Esquerdo & Positivo & Positivo & Negativo & Positivo & 1 & 1 & 1 & 1 & 4 & 1 & 1 & 3 \\
\hline 119 & Mastectomia & Direito & Positivo & Positivo & Negativo & Positivo & 1 & 1 & 1 & 1 & 4 & 1 & 1 & 1 \\
\hline 120 & Mastectomia & Esquerdo & Positivo & Positivo & Negativo & Negativo & 1 & 1 & 1 & 1 & 4 & 1 & 1 & 1 \\
\hline 121 & Quadrantectomia & Esquerdo & Positivo & Positivo & Negativo & Negativo & 1 & 1 & 1 & 1 & 1 & 1 & 1 & 3 \\
\hline 122 & Quadrantectomia & Direito & Positivo & Positivo & Positivo & Negativo & 0 & 1 & 0 & 0 & 0 & 1 & 1 & 1 \\
\hline 123 & Mastectomia & Esquerdo & Positivo & Positivo & Negativo & Positivo & 1 & 1 & 1 & 1 & 4 & 1 & 1 & 1 \\
\hline 124 & Mastectomia & Esquerdo & Positivo & Positivo & Positivo & Negativo & 1 & 2 & 1 & 1 & 4 & 1 & 1 & 1 \\
\hline 125 & Mastectomia & Esquerdo & Positivo & Negativo & Positivo & Negativo & 1 & 1 & 1 & 1 & 1 & 1 & 1 & 3 \\
\hline 126 & Mastectomia & Direito & Positivo & Positivo & Negativo & Positivo & 1 & 1 & 1 & 1 & 4 & 1 & 1 & 1 \\
\hline 127 & Mastectomia & Direito & Positivo & Positivo & Negativo & Positivo & 1 & 1 & 1 & 1 & 4 & 2 & 1 & 4 \\
\hline 128 & Setorectomia & Esquerdo & Positivo & Positivo & Negativo & Negativo & 3 & 1 & 1 & 1 & 1 & 2 & 1 & 2 \\
\hline 129 & Quadrantectomia & Esquerdo & Negativo & Negativo & Positivo & Positivo & 1 & 1 & 1 & 4 & 4 & 1 & 1 & 2 \\
\hline 130 & BAG & Direito & Negativo & Negativo & Negativo & Positivo & 4 & 3 & 1 & 1 & 4 & 3 & 1 & 2 \\
\hline 131 & Mastectomia & Direito & Negativo & Negativo & Negativo & Negativo & 4 & 4 & 4 & 1 & 4 & 1 & 1 & 1 \\
\hline 132 & Mastectomia & Direito & Positivo & Positivo & Negativo & Negativo & 1 & 1 & 1 & 1 & 4 & 1 & 1 & 4 \\
\hline 133 & Mastectomia & Esquerdo & Negativo & Negativo & Negativo & Positivo & 4 & 1 & 1 & 1 & 4 & 1 & 1 & 1 \\
\hline 134 & Mastectomia & Esquerdo & Negativo & Negativo & Negativo & Positivo & 4 & 1 & 3 & 1 & 1 & 1 & 1 & 3 \\
\hline
\end{tabular}


8. Referências 
(1) Brasil. Ministério da Saúde. Estimativa da Incidência e Mortalidade de Câncer no Brasil. Neoplasia maligna da próstata neoplasia maligna da mama feminina. Disponível em: http://www.inca.gov.br/estimativa/2006/index.asp?link=mapa.asp\&ID=13 . Acesso em: 1 jan. 2007.

(2) Bocker W. Preneoplasia of the breast. Verh Dtsch Ges Pathol 1997; 81:502-513.

(3) Cariati M, Purushotham AD. Stem cells and breast cancer. Histopathology 2008; 52(1):99-107.

(4) Stingl J, Caldas C. Molecular heterogeneity of breast carcinomas and the cancer stem cell hypothesis. Nat Rev Cancer 2007; 7(10):791-799.

(5) Fitzgibbons PL, Page DL, Weaver D, Thor AD, Allred DC, Clark GM et al. Prognostic factors in breast cancer. College of American Pathologists Consensus Statement 1999. Arch Pathol Lab Med 2000; 124(7):966-978.

(6) Wolff AC, Hammond ME, Schwartz JN, Hagerty KL, Allred DC, Cote RJ et al. American Society of Clinical Oncology/College of American Pathologists Guideline Recommendations for Human Epidermal Growth Factor Receptor 2 Testing in Breast Cancer. Arch Pathol Lab Med 2007; 131(1):18.

(7) Mirza AN, Mirza NQ, Vlastos G, Singletary SE. Prognostic factors in node-negative breast cancer: a review of studies with sample size more than 200 and follow-up more than 5 years. Ann Surg 2002; 235(1):10-26.

(8) Goldhirsch A, Wood WC, Gelber RD, Coates AS, Thurlimann B, Senn HJ. Progress and promise: highlights of the international expert consensus on the primary therapy of early breast cancer 2007. Ann Oncol 2007; 18(7):1133-1144. 
(9) Perou CM, Sorlie T, Eisen MB, van de RM, Jeffrey SS, Rees CA et al. Molecular portraits of human breast tumours. Nature 2000; 406(6797):747-752.

(10) Sorlie T, Perou CM, Tibshirani R, Aas T, Geisler S, Johnsen H et al. Gene expression patterns of breast carcinomas distinguish tumor subclasses with clinical implications. Proc Natl Acad Sci U S A 2001; 98(19):10869-10874.

(11) West M, Blanchette C, Dressman H, Huang E, Ishida S, Spang R et al. Predicting the clinical status of human breast cancer by using gene expression profiles. Proc Natl Acad Sci U S A 2001; 98(20):11462-11467.

(12) Sotiriou C, Neo SY, McShane LM, Korn EL, Long PM, Jazaeri A et al. Breast cancer classification and prognosis based on gene expression profiles from a population-based study. Proc Natl Acad Sci U S A 2003; 100(18):10393-10398.

(13) Sorlie T, Tibshirani R, Parker J, Hastie T, Marron JS, Nobel A et al. Repeated observation of breast tumor subtypes in independent gene expression data sets. Proc Natl Acad Sci U S A 2003; 100(14):8418-8423.

(14) 't Veer LJ, Dai H, van de Vijver MJ, He YD, Hart AA, Mao M et al. Gene expression profiling predicts clinical outcome of breast cancer. Nature 2002; 415(6871):530-536.

(15) Birnbaum D, Bertucci F, Ginestier C, Tagett R, Jacquemier J, CharafeJauffret $E$. Basal and luminal breast cancers: basic or luminous? (review). Int J Oncol 2004; 25(2):249-258.

(16) van de RM, Perou CM, Tibshirani R, Haas P, Kallioniemi O, Kononen $\mathrm{J}$ et al. Expression of cytokeratins 17 and 5 identifies a group of breast carcinomas with poor clinical outcome. Am J Pathol 2002; 161(6):1991-1996.

(17) Nielsen TO, Hsu FD, Jensen K, Cheang M, Karaca G, Hu Z et al. Immunohistochemical and clinical characterization of the basal-like subtype of invasive breast carcinoma. Clin Cancer Res 2004; 10(16):5367-5374.

(18) Livasy CA, Karaca G, Nanda R, Tretiakova MS, Olopade OI, Moore DT et al. Phenotypic evaluation of the basal-like subtype of invasive breast carcinoma. Mod Pathol 2006; 19(2):264-271.

(19) Loi S, Haibe-Kains B, Desmedt C, Lallemand F, Tutt AM, Gillet C et al. Definition of clinically distinct molecular subtypes in estrogen receptorpositive breast carcinomas through genomic grade. J Clin Oncol 2007; 25(10):1239-1246. 
(20) Paik S, Shak S, Tang G, Kim C, Baker J, Cronin M et al. A multigene assay to predict recurrence of tamoxifen-treated, node-negative breast cancer. N Engl J Med 2004; 351(27):2817-2826.

(21) Buyse M, Loi S, van't Veer L, Viale G, Delorenzi M, Glas AM et al. Validation and clinical utility of a 70-gene prognostic signature for women with node-negative breast cancer. J Natl Cancer Inst 2006; 98(17):1183-1192.

(22) Rouzier R, Perou CM, Symmans WF, Ibrahim N, Cristofanilli M, Anderson $\mathrm{K}$ et al. Breast cancer molecular subtypes respond differently to preoperative chemotherapy. Clin Cancer Res 2005; 11(16):5678-5685.

(23) Goldstein NS, Decker D, Severson D, Schell S, Vicini F, Margolis J et al. Molecular classification system identifies invasive breast carcinoma patients who are most likely and those who are least likely to achieve a complete pathologic response after neoadjuvant chemotherapy. Cancer 2007; 110(8):1687-1696.

(24) Wetzels RH, Kuijpers HJ, Lane EB, Leigh IM, Troyanovsky SM, Holland $\mathrm{R}$ et al. Basal cell-specific and hyperproliferation-related keratins in human breast cancer. Am J Pathol 1991; 138(3):751-763.

(25) Korsching E, Packeisen J, Agelopoulos K, Eisenacher M, Voss R, Isola $\mathrm{J}$ et al. Cytogenetic alterations and cytokeratin expression patterns in breast cancer: integrating a new model of breast differentiation into cytogenetic pathways of breast carcinogenesis. Lab Invest 2002; 82(11):1525-1533.

(26) van de RM, Gilks CB. Applications of microarrays to histopathology. Histopathology 2004; 44(2):97-108.

(27) Abd El-Rehim DM, Pinder SE, Paish CE, Bell J, Blamey RW, Robertson JF et al. Expression of luminal and basal cytokeratins in human breast carcinoma. J Pathol 2004; 203(2):661-671.

(28) Press MF, Sauter G, Bernstein L, Villalobos IE, Mirlacher M, Zhou JY et al. Diagnostic evaluation of HER-2 as a molecular target: an assessment of accuracy and reproducibility of laboratory testing in large, prospective, randomized clinical trials. Clin Cancer Res 2005; 11(18):6598-6607.

(29) Joensuu $\mathrm{H}$, Kellokumpu-Lehtinen PL, Bono P, Alanko T, Kataja V, Asola $\mathrm{R}$ et al. Adjuvant docetaxel or vinorelbine with or without trastuzumab for breast cancer. N Engl J Med 2006; 354(8):809-820.

(30) Romond EH, Perez EA, Bryant J, Suman VJ, Geyer CE, Jr., Davidson NE et al. Trastuzumab plus adjuvant chemotherapy for operable HER2positive breast cancer. N Engl J Med 2005; 353(16):1673-1684. 
(31) Piccart MJ, de Valeriola D, Dal Lago L, de Azambuja E, Demonty G, Lebrun $\mathrm{F}$ et al. Adjuvant chemotherapy in 2005: standards and beyond. Breast 2005; 14(6):439-445.

(32) Slamon D, Pegram M. Rationale for trastuzumab (Herceptin) in adjuvant breast cancer trials. Semin Oncol 2001; 28(1 Suppl 3):13-19.

(33) Hayes DF, Picard MH. Heart of darkness: the downside of trastuzumab. $J$ Clin Oncol 2006; 24(25):4056-4058.

(34) Konecny G, Pauletti G, Pegram M, Untch M, Dandekar S, Aguilar Z et al. Quantitative association between HER-2/neu and steroid hormone receptors in hormone receptor-positive primary breast cancer. J Natl Cancer Inst 2003; 95(2):142-153.

(35) Ellis MJ. Neoadjuvant endocrine therapy for breast cancer: medical perspectives. Clin Cancer Res 2001; 7(12 Suppl):4388s-4391s.

(36) Villman K, Sjostrom J, Heikkila R, Hultborn R, Malmstrom P, Bengtsson $\mathrm{NO}$ et al. TOP2A and HER2 gene amplification as predictors of response to anthracycline treatment in breast cancer. Acta Oncol 2006; 45(5):590-596.

(37) Durbecq V, Desmed C, Paesmans M, Cardoso F, Di Leo A, Mano M et al. Correlation between topoisomerase-llalpha gene amplification and protein expression in HER-2 amplified breast cancer. Int J Oncol 2004; 25(5):1473-1479.

(38) Lakhani SR, Reis-Filho JS, Fulford L, Penault-Llorca F, van d, V, Parry $S$ et al. Prediction of BRCA1 status in patients with breast cancer using estrogen receptor and basal phenotype. Clin Cancer Res 2005; 11(14):5175-5180.

(39) Wakeling AE, Nicholson RI, Gee JM. Prospects for combining hormonal and nonhormonal growth factor inhibition. Clin Cancer Res 2001; 7(12 Suppl):4350s-4355s.

(40) Chan KC, Knox WF, Gee JM, Morris J, Nicholson RI, Potten CS et al. Effect of epidermal growth factor receptor tyrosine kinase inhibition on epithelial proliferation in normal and premalignant breast. Cancer Res 2002; 62(1):122-128.

(41) Yared MA, Middleton LP, Meric F, Cristofanilli M, Sahin AA. Expression of c-kit proto-oncogene product in breast tissue. Breast J 2004; 10(4):323-327.

(42) Folkman J, Watson K, Ingber D, Hanahan D. Induction of angiogenesis during the transition from hyperplasia to neoplasia. Nature 1989; 339(6219):58-61. 
(43) Ludovini V, Sidoni A, Pistola L, Bellezza G, De A, V, Gori S et al. Evaluation of the prognostic role of vascular endothelial growth factor and microvessel density in stages I and II breast cancer patients. Breast Cancer Res Treat 2003; 81(2):159-168.

(44) Ribeiro-Silva A, Ribeiro d, V, Zucoloto S. Vascular endothelial growth factor expression in the basal subtype of breast carcinoma. Am J Clin Pathol 2006; 125(4):512-518.

(45) Ellis LM. Current overview of angiogenesis inhibitors. Clin Adv Hematol Oncol 2004; 2(8):494-6, 520.

(46) Arnes JB, Brunet JS, Stefansson I, Begin LR, Wong N, Chappuis PO et al. Placental cadherin and the basal epithelial phenotype of BRCA1related breast cancer. Clin Cancer Res 2005; 11(11):4003-4011.

(47) Honrado E, Benitez J, Palacios J. The molecular pathology of hereditary breast cancer: genetic testing and therapeutic implications. Mod Pathol 2005; 18(10):1305-1320.

(48) Gusterson BA, Ross DT, Heath VJ, Stein T. Basal cytokeratins and their relationship to the cellular origin and functional classification of breast cancer. Breast Cancer Res 2005; 7(4):143-148.

(49) Abd El-Rehim DM, Pinder SE, Paish CE, Bell JA, Rampaul RS, Blamey RW et al. Expression and co-expression of the members of the epidermal growth factor receptor (EGFR) family in invasive breast carcinoma. Br J Cancer 2004; 91(8):1532-1542.

(50) Foulkes WD, Brunet JS, Stefansson IM, Straume O, Chappuis PO, Begin LR et al. The prognostic implication of the basal-like (cyclin $E$ high/p27 low/p53+/glomeruloid-microvascular-proliferation+) phenotype of BRCA1-related breast cancer. Cancer Res 2004; 64(3):830-835.

(51) Boecker W, Buerger $\mathrm{H}$. Evidence of progenitor cells of glandular and myoepithelial cell lineages in the human adult female breast epithelium: a new progenitor (adult stem) cell concept. Cell Prolif 2003; 36 Suppl $1: 73-84$.

(52) Sell S, Pierce GB. Maturation arrest of stem cell differentiation is a common pathway for the cellular origin of teratocarcinomas and epithelial cancers. Lab Invest 1994; 70(1):6-22.

(53) Leibl S, Gogg-Kammerer M, Sommersacher A, Denk H, Moinfar F. Metaplastic breast carcinomas: are they of myoepithelial differentiation?: immunohistochemical profile of the sarcomatoid subtype using novel myoepithelial markers. Am J Surg Pathol 2005; 29(3):347-353. 
(54) Kordon EC, Smith GH. An entire functional mammary gland may comprise the progeny from a single cell. Development 1998; 125(10):1921-1930.

(55) Stingl J, Raouf A, Emerman JT, Eaves CJ. Epithelial progenitors in the normal human mammary gland. J Mammary Gland Biol Neoplasia 2005; 10(1):49-59.

(56) Behbod F, Rosen JM. Will cancer stem cells provide new therapeutic targets? Carcinogenesis 2005; 26(4):703-711.

(57) Bryan BB, Schnitt SJ, Collins LC. Ductal carcinoma in situ with basallike phenotype: a possible precursor to invasive basal-like breast cancer. Mod Pathol 2006; 19(5):617-621.

(58) Livasy CA, Perou CM, Karaca G, Cowan DW, Maia D, Jackson S et al. Identification of a basal-like subtype of breast ductal carcinoma in situ. Hum Pathol 2007; 38(2):197-204.

(59) Elston CW, Ellis IO. Pathology and breast screening. Histopathology 1990; 16(2):109-118.

(60) Ellis I, Schnitt SJ, Sastre-Garau X, Bussolati G, Tavassoli FA, Eusebi V et al. Tumours of the breast. In: Tavassoli FA, Devilee P, editors. WORLD HEALTH ORGANIZATION CLASSIFICATION OF TUMOURS. PATHOLOGY \& GENETICS - Tumours of the Breast and Female Genital Organs. Lyon: IARC Press, 2003: 9-112.

(61) Elston CW, Ellis IO. Pathological prognostic factors in breast cancer. I. The value of histological grade in breast cancer: experience from a large study with long-term follow-up. Histopathology 1991; 19(5):403-410.

(62) Motulsky H. Multiple Comparisons. Intuitive Biostatistics. New York, NY: Oxford University Press, 1995.

(63) Brenton JD, Carey LA, Ahmed AA, Caldas C. Molecular classification and molecular forecasting of breast cancer: ready for clinical application? J Clin Oncol 2005; 23(29):7350-7360.

(64) Foulkes WD, Stefansson IM, Chappuis PO, Begin LR, Goffin JR, Wong $\mathrm{N}$ et al. Germline BRCA1 mutations and a basal epithelial phenotype in breast cancer. J Natl Cancer Inst 2003; 95(19):1482-1485.

(65) van de Vijver MJ, He YD, Van't Veer LJ, Dai H, Hart AA, Voskuil DW et al. A gene-expression signature as a predictor of survival in breast cancer. N Engl J Med 2002; 347(25):1999-2009.

(66) Malzahn K, Mitze M, Thoenes M, Moll R. Biological and prognostic significance of stratified epithelial cytokeratins in infiltrating ductal breast carcinomas. Virchows Arch 1998; 433(2):119-129. 
(67) Matos I, Dufloth R, Alvarenga M, Zeferino LC, Schmitt F. p63, cytokeratin 5, and P-cadherin: three molecular markers to distinguish basal phenotype in breast carcinomas. Virchows Arch 2005; 447(4):688-694.

(68) Rakha EA, El Sayed ME, Green AR, Paish EC, Lee AH, Ellis IO. Breast carcinoma with basal differentiation: a proposal for pathology definition based on basal cytokeratin expression. Histopathology 2007; 50(4):434-438.

(69) Fulford LG, Reis-Filho JS, Ryder K, Jones C, Gillett CE, Hanby A et al. Basal-like grade III invasive ductal carcinoma of the breast: patterns of metastasis and long-term survival. Breast Cancer Res 2007; 9(1):R4.

(70) Fulford LG, Easton DF, Reis-Filho JS, Sofronis A, Gillett CE, Lakhani SR et al. Specific morphological features predictive for the basal phenotype in grade 3 invasive ductal carcinoma of breast. Histopathology 2006; 49(1):22-34. 
Apêndice 


\section{Legenda do cadastro com dados anátomo-patológicos e resultados do estudo imunoistoquímico}

- № Caso - número do caso de cada paciente

- Idade - idade da paciente

- L Dissecados - número de linfonodos axilares dissecados

- L Positivos - número de linfonodos axilares dissecados positivos

- L Tamanho - tamanho do maior linfonodo axilar dissecado (cm)

- $\mathrm{pN}$ - estadiamento dos linfonodos axilares

- $\quad \mathrm{T}$ - tamanho do tumor no maior eixo $(\mathrm{cm})$

- Tipo Histológico - CDI - Carcinoma Ductal Invasivo; Outro - outro tipo histológico, não CDI

- Grau Histológico - 2 - carcinoma com grau histológico de Nottingham 2, porém com grau tubular 3; 3 - carcinoma com grau histológico de Nottingham 3

- Grau Tubular - 3 - ausência ou presença em até 10\% de formação tubular

- Grau Pleomorfismo - 2-pleomofismo celular moderado; 3 -pleomorfismo celular intenso

- Mitoses - 1- 0 a 5 mitoses/campos de grande aumento; 2- 6 a 11 mitoses/campos de grande aumento; 3 - mais do que 12 mitoses/campos de grande aumento.

- CDIS - sim - presença de Carcinoma Ductal "in situ" associado; não ausência de Carcinoma Ductal "in situ".

- EVL - sim - presença de embolização vascular linfática associada; não ausência de embolização vascular linfática.

- Necrose - sim - presença de necrose tumoral; não - ausência de necrose tumoral.

- Procedimento - BAG - biópsia por agulha grossa; quadrantectomia; mastectomia; adenectomia. 
- Lateralidade - Direito; Esquerdo; Desconhecido.

- RE - positivo - pelo menos $1 \%$ das células tumorais invasivas coradas; Negativo - ausência de células tumorais invasivas coradas.

- RP - positivo - pelo menos $1 \%$ das células tumorais invasivas coradas; Negativo - ausência de células tumorais invasivas coradas.

- HER2 - positivo - escore 3+ (ASCO/CAP); negativo - escore 1+ ou 2+.

- Ki67 - positivo - > 50\% das células tumorais invasivas coradas; negativo $<50 \%$ das células tumorais invasivas coradas.

- CK5 - 0 - material insuficiente; 1-negativo - ausência de células tumorais invasivas coradas; 2 - positivo $-<25 \%$ das células tumorais invasivas coradas; 3 -positivo - de $25-50 \%$ das células tumorais invasivas coradas e 4 - positivo - $>50 \%$ das células tumorais invasivas coradas.

- CK14 - 0 - material insuficiente; 1-negativo - ausência de células tumorais invasivas coradas; 2 - positivo $-<25 \%$ das células tumorais invasivas coradas; 3 -positivo - de $25-50 \%$ das células tumorais invasivas coradas e 4 - positivo - $>50 \%$ das células tumorais invasivas coradas.

- CK17 - 0 - material insuficiente; 1-negativo - ausência de células tumorais invasivas coradas; 2 - positivo $-<25 \%$ das células tumorais invasivas coradas; 3 -positivo - de $25-50 \%$ das células tumorais invasivas coradas e 4 - positivo - $>50 \%$ das células tumorais invasivas coradas.

- EGFR - 0 - material insuficiente; 1-negativo - ausência de células tumorais invasivas coradas; 2 - positivo $-<25 \%$ das células tumorais invasivas coradas; 3 -positivo - de $25-50 \%$ das células tumorais invasivas coradas e 4 - positivo - $>50 \%$ das células tumorais invasivas coradas.

- CK8/18 - 0 - material insuficiente; 1 - negativo - ausência de células tumorais invasivas coradas; 2 - positivo $-<25 \%$ das células tumorais invasivas coradas; 3 -positivo - de $25-50 \%$ das células tumorais invasivas coradas e 4 - positivo - $>50 \%$ das células tumorais invasivas coradas.

- cKit - 0 - material insuficiente; 1-negativo - ausência de células tumorais invasivas coradas; 2 - positivo $-<25 \%$ das células tumorais invasivas coradas; 3 -positivo - de $25-50 \%$ das células tumorais invasivas coradas e 4 - positivo - $>50 \%$ das células tumorais invasivas coradas. 
- p63 - 0 - material insuficiente; 1-negativo - ausência de células tumorais invasivas coradas; 2 - positivo $-<25 \%$ das células tumorais invasivas coradas; 3 -positivo - de $25-50 \%$ das células tumorais invasivas coradas e 4 - positivo - $>50 \%$ das células tumorais invasivas coradas.

- VEGF-A - 0 - material insuficiente; 1 - negativo - ausência de células tumorais invasivas coradas; 2 - positivo $-<25 \%$ das células tumorais invasivas coradas; 3 -positivo - de $25-50 \%$ das células tumorais invasivas coradas e 4 - positivo - $>50 \%$ das células tumorais invasivas coradas. 